\title{
DRUŠTVO S OGRANIČENOM ODGOVORNOŠĆU U SVJETLU NOVELE ZAKONA O TRGOVAČKIM DRUŠTVIMA IZ 2019.
}

UDK: $347.7(497.5)$

DOI: 10.31141/ZRPFS.2020.57.136.551

Pregledni znanstveni rad

Primljeno: 10. rujna 2019.

Izlažu se i komentiraju odredbe o društvu s ograničenom odgovornošću koje su se izmijenile i dopunile Novelom Zakona o trgovačkim društvima u 2019. Povod njezinu donošenju jest uvođenje rješenja iz Direktive (EU) 2017/828 Europskog parlamenta i Vijeća od 17. svibnja 2017. u pogledu poticanja dugoročnog sudjelovanja dioničara (dalje: Direktiva 2017/828) u hrvatski pravni poredak, ali se njime značajno zadrlo i u materiju uređenja d.o.o.-a. Izmijenjene su odredbe o ulozima za preuzete poslovne udjele, o raspolaganju poslovnim udjelom, o jednostavnom društvu s ograničenom odgovornošću, a Zakon se dopunjuje s dva potpuno nova odjeljka naslovljena: „Osnivanje društva na daljinu bez punomoćnika“ i „Prestanak društva po skraćenom postupku“. Pravnopolitički cilj, učiniti hrvatsko gospodarstvo konkurentnijim i ulagačima privlačnijim, pokušao se ostvariti olakšanjem, kako osnivanja, tako i prestanka društava. Detaljno se raspravlja o jednostavnom društvu s ograničenom odgovornošću i kritički osvrće na proširenje broja osnivača toga društva, a de lege ferenda predlaže se njegovo ukidanje. Nakon izlaganja o novoj mogućnosti osnivanja trgovačkog društva elektroničkim putem, zakonska se rješenja podvrgavaju kritici a temeljni razlog zabrinutosti krije se u činjenici isključenja javnih bilježnika iz postupka osnivanja društva. Ne samo da se na taj način osnivačima onemogućuje da budu upoznati o pravima, dužnostima i rizicima kojima se izlažu ulaskom u poduzetnički pothvat, već se time potkopava pravna sigurnost zbog mogućeg povećanja računalnog kriminaliteta i zaobilaženja odredbi o sprečavanju pranja novca. Komentira se mogućnost prestanka društva po skraćenom postupku i mjere zaštite vjerovnika. Zaključno se daje kritički osvrt na određene odredbe i institute prava društva s ograničenom odgovornošću i de lege ferenda predlažu rješenja koja bi se u budućnosti mogla utkati u Nacrt novih izmjena i dopuna Zakona.

Ključne riječi: jednostavno društvo s ograničenom odgovornošću, osnivanje društva na daljinu, prestanak društva po skraćenom postupku, zaštita vjerovnika 


\section{UVOD}

Zakon o trgovačkim društvima ${ }^{1}$ temeljni je legislativni instrument kojim se uređuju nastanak, unutarnji odnosi u društvu, zastupanje, odgovornost, djelovanje i prestanak trgovačkih društava. Njegova vrsnoća i usklađenost s drugim zakonima čiji su predmet uređenja, kako odnosi sudionika na tržištu međusobno, tako i (su) djelovanje javne vlasti u gospodarstvu, okosnica su ostvarenja slobodnog tržišna. Kako se primjenjuje od 1. siječnja 1995. to je jedan od trajnijih propisa donesen u Republici Hrvatskoj. ${ }^{2}$ Trgovačka se društva permanentno razvijaju, preobražavaju i mijenjaju. Bilo da se radi o internim potrebama reagiranja na pojave nedosljedne primjene prava, ili na pojave zlouporabe postojećih pravnih instituta, ili se to tiče nužnosti prilagodbe pravnoj stečevini Europske unije, naš zakonodavac mora kontinuirano mijenjati i nadopunjavati postojeća zakonska rješenja. Novela ZTD$\mathrm{a}^{3}$ od 15. travnja 2019. deseta je izmjena i dopuna ZTD-a. ${ }^{4}$

Povod njezinu donošenju jest uvođenje rješenja iz Direktive (EU) 2017/828 Europskog parlamenta i Vijeća od 17. svibnja 2017. u pogledu poticanja dugoročnog sudjelovanja dioničara (dalje: Direktiva 2017/828) u hrvatski pravni poredak. Sadržaj je Novele, međutim, znatno širi od unosa relevantnih odredbi iz navedene Direktive, jer se izmijenilo, dopunilo ili brisalo niz odredbi iz općeg dijela ZTD-a, kao i odredbi o dioničkom društvu i društvu s ograničenom odgovornošću. ${ }^{6}$ Radi

1 Zakon o trgovačkim društvima, Narodne novine br. 111/93, 34/99, 121/99 - vjerodostojno tumačenje, 52/00- Odluka Ustavnog suda RH, 118/03, 107/07, 146/08, 137/09, 125/11, 111/12, 68/13, 110/15, 40/19. (dalje: ZTD i Zakon).

2 Po opsegu i predmetu uređenja značajni zakoni rijetko su bili na snazi (u primjeni) dulje od dvadeset godina. Doduše, postoje neki propisi koji su na snazi još od 8. listopada 1991. kada se povodom stvaranja samostalne države preuzeo dio pravnog poretka bivše federacije (pravnicima poznato preuzimanje tadašnjih propisa koji nisu bili u suprotnosti s odredbama Ustava Republike Hrvatske; Narodne novine, br. 51/91). Tako je, primjerice, sve do 29. siječnja ove godine na snazi bio Zakon o rješavanju sukoba zakona s propisima drugih zemalja u određenim odnosima iz 1982., kojeg je nakon dvadeset i osam godina hrvatske samostalnosti zamijenio Zakon o međunarodnom privatnom pravu, Narodne novine br. 101/18.

3 Zakon o izmjenama i dopunama ZTD-a, Narodne novine br. 40/19. (dalje: Novela ZTD-a).

4 Zakonodavnim je putem ZTD do sada mijenjan i nadopunjavan deset puta, a uz to su se dogodile još dvije ,vanjske“ intervencije u njegov sadržaj: Vjerodostojno tumačenje Hrvatskog sabora od 19. studenog 1999. i odluka Ustavnog suda Republike Hrvatske od 10. svibnja 2010. Po opsegu su najznačajnije novele ZTD-a donesene 2003., 2007., 2009. i 2012., a s njima je usporediva i ova najnovija.

5 Republika Hrvatska je na temelju čl. 2. st. 1. Direktive 2017/828 dužna izvršiti njezino prenošenje u nacionalne propise do 10. lipnja 2019., a to se učinilo izmjenama i dopunama ZTD-a. Novela je opsežna i sadrži devedeset članaka, od kojih gotovo trećina otpada na brisanje nekog članka, stavka, sintagme ili riječi, ili se radi o redakcijskom poboljšanju i usklađenju nazivlja, a oko dvije trećine članaka sadrže odredbe kojima se supstancijalno mijenjaju i nadopunjuju dosadašnja zakonska rješenja. Vlada Republike Hrvatske kao predlagatelj navodi taj razlog kao povod donošenju Novele ZTD-a. V. Prijedlog Vlade RH iz ožujka 2017., str. 3. Više o tome v. https//www.vlada.gov.hr. Stranica pregledana 10. rujna 2019.

6 U radu se neće razmatrati izmjene i dopune odredbi iz općeg dijela Zakona, kao ni odredbe kojima se uređuje dioničko društvo. Odredbe o javnom trgovačkom društvu i gospodarskom interesnom udruženju neznatno su izmijenjene, a tiču se izmjena općih odredbi u svezi s predmetom poslovanja ili načina pohrane poslovnih knjiga i dokumentacije po okončanju likvidacije i brisanja društva iz sudskog registra. Odredbe o komanditnom društvu nisu se mijenjale, ali s obzirom na primjenu odredbi kojima se uređuje javno trgovačko društvo, izmjene pojedinih odredbi u tome društvu odnose se i na odnose $u$ komanditnom društvu. Neće se razmatrati niti izmjene i dopune odredbi o povezanim društvima, odredbi o inozemnim trgovačkim društvima, kaznenih odredbi i prijelaznih i završnih odredbi Zakona. 
provedbe propisa iz Novele ZTD-a, istodobno s njom, 20. travnja 2019. stupio je na snagu Zakon o izmjenama i dopunama zakona o sudskom registru ${ }^{7}$ kojim se uređuje tehnologija postupanja svih subjekata uključenih u postupak osnivanja, promjena i prestanak trgovačkih društava.

\section{NOVINE U UREĐENJU DRUŠTVA S OGRANIČENOM ODGOVORNOŠĆU}

\subsection{Općenito}

Novelom se značajno interveniralo u koherentno izgrađeni sustav prava društava s ograničenom odgovornošću. Uz nomotehničku prilagodbu odgovarajućih odredbi izmjenama i dopunama općeg dijela Zakona, izmjenjuju se odredbe o ulozima za preuzete poslovne udjele, o raspolaganju poslovnim udjelom, o jednostavnom društvu s ograničenom odgovornošću, a Zakon se dopunjuje s dva potpuno nova odjeljka naslovljena: „Osnivanje društva na daljinu bez punomoćnika“ i „Prestanak društva po skraćenom postupku“ ${ }^{8}$ Pravnopolitički cilj, učiniti hrvatsko gospodarstvo konkurentnijim i ulagačima privlačnijim, pokušao se ostvariti olakšanjem, kako osnivanja, tako i prestanka društava. ${ }^{9}$ Neprijeporno je da trendovi poslovanja bez papira i elektronički prijenos informacija postaju standard komunikacije u poslovnom svijetu. Posebice je važno raščlaniti administrativno, pravno i poslovno okružje u kojem djeluju nositelji poduzetničkih aktivnosti u Republici Hrvatskoj. Ako su mjere kojima se rasterećuju poduzetnici odmjereno uklopljene u postojeći pravni i gospodarski sustav, one potiču razvoj poduzetništva, a contrario one mogu i sputavati njegov razvoj. Posebice treba osluškivati i prepoznavati promjene koje se događaju u europskom gospodarskom području i ispravno reagirati izmjenom i/ili dopunom relevantnih propisa. Preporučljivo se ugledati na pravna rješenja koja se stvaraju u nama bliskom srednjoeuropskom pravnom krugu, a pritom bi njemačko pravo društva kao uzor našem sustavu prava društava trebalo biti nezaobilazno. Međutim, rješenja iz drugih pravnih sustava, makar se radilo i o pravu uzoru, treba prihvaćati kritički kako bi se bez poteškoća uklopila u postojeći sustav prava društava. Važno je razmotriti potrebu preuzimanja rješenja iz pravno neobvezujućih dijelova Direktiva, Preporuka, Strategija i sl. Europske unije ili nekih drugih međunarodnih institucija ili usporednih pravnih sustava. Jesu li izmjene i dopune odredbi kojima se uređuju odnosi u društtvu s ograničenom odgovornošću

7 Zakon o sudskom registru, Narodne novine br. 40/19 (nadalje Novela ZSR-a). U svojem dvadesetčetverogodišnjem trajanju Zakon o sudskom registru do sada je dvanaest puta bio mijenjan i nadopunjavan: Narodne novine br. 1/95, 57/96, 1/98, 30/99, 45/99, 54/05, 40/07, 91/10, 90/11, 148/13, 93/14, 110/15. i 40/19 (nadalje ZSR). Kako je već odavno istekao propisani tromjesečni rok za usklađenje Pravilnika o načinu upisa u sudski registar (Narodne novine br. 22/12, 127/14) s Novelom ZSR-a, nužno je to što prije učiniti.

8 Arg. ex čl. 61.-75. Novele ZTD-a.

9 V. Prijedlog Vlade RH iz ožujka 2017., str. 4. Više o tome v. https//www.vlada.gov.hr. Stranica pregledana 10. rujna 2019. 
bile nužne? Jesu li odredbe kojima se mijenjaju ili nadopunjuju postojeće odredbe ispravno sročene? Je li uopće za naše gospodarsko i pravno okružje bolje da postoji mogućnost osnivanja jednostavnog društva s ograničenom odgovornošću ili ne? Je li lakoća i brzina osnivanja jednostavnog društva s ograničenom odgovornošću važnija od zaštite vjerovnika? Doprinosi li „nepodnošljiva lakoća postojanja“ toga društva lakšem zaobilaženju, primjerice poreznih propisa, ili? Hoće li mogućnost osnivanja društva na daljinu bez sudjelovanja stručnih osoba učiniti Republiku Hrvatsku poželjnijim investicijskim ciljem, ili će se time, a contrario, dodatno potkopati pravna sigurnost? U praksi se pokazalo da prestanak društva s ograničenom odgovornošću provođenjem likvidacije društva može biti nepotrebno dug i skup, pa svakako treba pozdraviti novu mogućnost prestanka društava po skraćenom postupku. Mogu li se usredotočenjem na zaštitu vjerovnika ugroziti interesi društva i članova s manjinskim udjelima? Nastavak rada je pokušaj pronalaženja razloga koji bi mogli potkrijepiti odgovore na navedena pitanja.

\subsection{Ulozi za preuzete poslovne udjele}

Prije upisa društva u sudski registar svaki osnivač mora za preuzete poslovne udjele uplatiti najmanje četvrtinu uloga za preuzeti poslovni udio koji uplaćuje u novcu, s tim da ukupan iznos svih uplata u novcu ne može biti manji od jedne četvrtine temeljnog kapitala. Odredba čl. 290. st. 2. ZTD-a izmijenila se tako da je a) promijenjen najniži prag uloga za preuzeti poslovni udio koji se uplaćuje u novcu, b) ulog u novcu mora se u cijelosti unijeti u roku od godine dana od dana upisa društva u sudski registar i c) osnivač koji nije uplatio ulog za preuzeti poslovni udjel odgovara za obveze društva osobno i solidarno sa svim osnivačima koji nisu uplatili uloge za preuzete poslovne udjele do visine neuplaćenog temeljnog kapitala.

Više se ne traži da ukupni iznos svih uplata u novcu ne može biti manji od 10.000,00 kuna, već se traži da ukupan iznos svih uplata u novcu ne može biti manji od jedne četvrtine temeljnog kapitala društva. „Početni ulog“ u novcu prije upisa društva u sudski registar postaje varijabilan i ovisi o visini temeljnog kapitala utvrđenog u društvenom ugovoru ili izjavi o osnivanju društva, a njegov najmanje dopušteni iznos time je dvostruko smanjen i to na iznos od 5000,00 kuna. Takva će mjera doprinijeti povratu privlačnosti „klasičnog“ d.o.o.-a u odnosu na j.d.o.o. jer se s početno manjim ulozima može krenuti u poduzetnički pothvat, a na temelju načela unosa i održanja temeljnog kapitala ${ }^{10}$ društvu osiguravaju barem neka vlastita sredstva koja služe za obavljanje njegovih djelatnosti. Društvo neće biti obvezno stvoriti rezerve kapitala, a članovi će moći sadržaj društvenog ugovora prilagoditi svojim potrebama. Članovi će promišljenije odlučivati o svojem članstvu u društvu kapitala, nego li je to slučaj kod jednostavnog društva s ograničenom odgovornošću koje se može osnovati s beznačajnim ulogom. ${ }^{11}$

\footnotetext{
10 O načelima unosa i održanja kapitala društva detaljnije će se raspraviti u nastavku rada.

11 Više o tome u vidi u sljedećem poglavlju rada.
} 
Odredbe o unosu stvari i prava ostaju nepromijenjene, pa se ulog unošenjem u društvo stvari i prava mora u cjelini unijeti prije upisa društva u sudski registar. ${ }^{12}$ Novost je da se propisuje da ako ulog u novcu nije u cijelosti unesen prije osnivanja društva, to se mora učiniti u roku od godine dana od upisa društva u sudski registar. Osnivač koji nije uplatio ulog za preuzeti poslovni udjel odgovara za obveze društva osobno i solidarno sa svim drugim osnivačima koji nisu uplatili uloge za preuzete poslovne udjele do visine neuplaćenog temeljnog kapitala. ${ }^{13} \mathrm{Na}$ taj način odstupa se od načela da članovi društva kapitala ne odgovaraju za obveze društva osim u slučaju proboja pravne osobnosti zbog zloupotrebe okolnosti da ne odgovaraju za obveze društva. ${ }^{14}$ Svi osnivači koji nisu uplatili uloge za svoje poslovne udjele do visine neuplaćenog temeljnog kapitala odgovaraju za obveze društva. Pretpostavka za to nije zloupotreba koju bi trebalo dokazati i koja bi imala za posljedicu odgovornost bez ograničenja visine nego neispunjenje obveze uplate uloga za poslovni udio. Član društva može uredno ispunjavati svoje članske obveze jer unutar godine dana nije u zakašnjenju s obvezom uplate uloga, ali ga se kažnjava propisivanjem odgovornosti prema vjerovnicima za obveze društva. Pored toga, zanemaruje se koliko je tko uplatio za svoj poslovni udio pa se može dogoditi da netko od osnivača u konačnici uplati više nego što je bio dužan uplatiti društvu. ${ }^{15}$ Osobna i solidarna odgovornost člana za obveze društva, premda ograničena na iznos visine temeljnog kapitala, nije u skladu s temeljnom povlasticom koju uživaju članovi društava kapitala - neodgovornost za obveze društva. Zaštita vlastitog kapitala društva i zaštita interesa vjerovnika uravnoteženo se ostvaruje institutima unosa i održanja kapitala društva i proboja pravne osobnosti, pa je suvišna i neodmjerena odredba o ograničenoj odgovornosti osnivača za obveze društva do visine iznosa neuplaćenih uloga. Naime, za komanditno je društvo svojstveno da komanditor odgovara vjerovnicima društva neposredno i solidarno s ostalim članovima društva do visine ugovorenog uloga umanjenog za neuplaćeni dio, ali samo ako ne uplati u cjelini ulog na koji se obvezao društvenim ugovorom. ${ }^{16}$ Međutim, to je društvo osoba koje nema kategoriju temeljnog kapitala niti se na njega primjenjuju instituti unosa i održanja kapitala odnosno proboja pravne osobnosti. Nije dobro unutar ispravno podešenog mehanizma uravnoteženja interesa između članova društva i vjerovnika umetati ,dodatke“ kojima se dodatno štite vjerovnici, još je opasnije da se pri tome

12 Tako čl. 390. st. 3. ZTD-a.

13 Čl. 390. st. 2. ZTD-a. Odredba nije ispravno sročena jer se ne uplaćuje temeljni kapital nego ulozi za poslovne udjele s time da se uplate u poslovnim knjigama društva iskazuju kao iznos uplaćenog temeljnog kapitala. Stoga je ispravno bilo reći da se odgovora do visine iznosa neuplaćenih uloga za sve poslovne udjele u društvu. Tako vidi Barbić, J., „Novela Zakona o trgovačkim društvima u 2019.“, Zbornik 57. susreta pravnika, Opatija 2019., str. 46. i 47.

14 Ibidem.

15 To može biti dovedeno da apsurda tako da jedan osnivač/član društva koji samo neznatnim dijelom nije uplatio ulog podmiri vjerovnicima obveze društva do ukupne visine neuplaćenih uloga svih članova društva. Sve to dovodi do kasnijih sporova oko regresa koji mogu biti vrlo složeni i neizvjesni, naročito kako kod više članova i različitih iznosa uplate u različito vrijeme obračunati koliko se od koga može tražiti. Više o tome v. ibidem.

16 Tako čl. 143. st. 2. ZTD-a. 
ugleda na rješenja koja vrijede za društva osoba. Navedenom se odredbom ugrožava pravna sigurnost pa je de lege ferenda treba, što je prije moguće, ukinuti.

\subsection{Jednostavno društvo s ograničenom odgovornošću}

Kao alternativa osnivanju „običnog/klasičnog“ društva s ograničenom odgovornošću već sedam godina naš pravni poredak omogućuje osnivanje jednostavnog društva $s$ ograničenom odgovornošću (nadalje: j.d.o.o.). ${ }^{17}$ Takav pojavni oblik društva s ograničenom odgovornošću mogla su osnovati najviše tri člana. ${ }^{18}$ Novelom ZTD-a izmijenila se odredba u pogledu povećanja broja osnivača, pa se na pojednostavljeni način može osnovati društvo koje ima najviše pet članova i jednog člana uprave, a novina je i mogućnost njegova osnivanja elektroničkim putem. ${ }^{19}$ Ostale su odredbe sadržane u čl. 390.a ZTD-a (kojim se uređuje j.d.o.o.) ostale nepromijenjene. Odgovor na pitanje je li proširenje broja osnivača društva na pojednostavljeni način (s tri na pet) i mogućnost njegova osnivanja na daljinu bez punomoćnika dobro rješenje, pretpostavlja raščlambu odredbi čl. 390.a ZTD-a. Iz humusa razmatranih razloga trebao bi niknuti izdanak odgovora na pitanja: a) jesu li izmjene i/ili dopune bile nužne i optimalne, ili se trebalo značajnije intervenirati u sadržaj uređenja j.d.o.o.-a, b) je li trebalo izbrisati čl. 390.a i onemogućiti daljnje osnivanje j.d.o.o.-a i propisati način preustroja takvih društava u d.o.o. i odrediti rok za to.

\subsubsection{Ratio legis osnivanja društva na pojednostavljeni način}

Sloboda poslovnog nastana osigurana primarnim europskim pravom $^{20}$ trgovačkim društvima unutar Europske unije jamči slobodu osnivanja, organiziranja i preoblikovanja (njem. Gründungs-, Organisations- und Umwandlungsfreiheit). ${ }^{21} \mathrm{O}$ konkretnom opsegu tih sloboda odlučivao je Sud Europske unije tumačeći odredbe čl. 49. i 54. Ugovora o funkcioniranju Europske unije. U poznatim i u doktrini opsežno raspravljenim odlukama - Centros, Überseering i Inspire Art, Sud Europske unije uzdrmao je i potkopao u kontinentalnoeuropskom pravu vladajuću teoriju stvarnog sjedišta i potvrdio teoriju osnivanja koja je opravdala i omogućila, kako mobilnost trgovačkih društava unutar Europske unije, tako i premještanje upravnog sjedišta

17 U naš pravni poredak j.d.o.o. je uveden 2012. Zakonom o izmjenama i dopunama Zakona o trgovačkim društvima, Narodne novine br. 111/12.

18 Čl. 387. st. 2. u svezi s čl. 390.a st. 1. ZTD-a.

19 Čl. 390.a st. 1. i 379.a do 379.e ZTD-a.

20 Čl. 49. do 55. Ugovora o funkcioniranju Europske unije, OJ C 326.

21 Više o tome vidi Keiner, R., ,Eine Rechtsformvariante bewegt Europa“, Zeitschrift für Gesellschaft-, Unternehmens- und Steuerrecht der GmbH und GmbH \& Co. KG (nadalje: GmbHR), 22/18, str. 1182. 
izvan nje. ${ }^{22}$ Nakon takve autoritativne interpretacije odredbi o slobodi poslovnog nastana, trgovačko društvo koje je osnovano po pravu jedne države članice može na temelju teorije osnivanja zatražiti i postići priznanje svoje pravne osobnosti u drugoj državi članici, bez obzira na činjenicu gdje se stvarno obavljaju njegovi poslovi. To je potaklo posebice male poduzetnike da osnivaju trgovačka društva u onim državama članicama u kojima se ne traži spomena vrijedan ulog u društvo prilikom osnivanja, te nema dodatnih administrativnih zapreka niti troškova. Poduzetnici iz zemalja kontinentalng pravnog kruga identificirali su Ujedinjeno Kraljevstvo kao najprivlačniju zemlju za jeftino i brzo osnivanje trgovačkog društva kapitala private company limited by shares (Limited) koje odgovara kontinentalnom društvu s ograničenom odgovornošću. ${ }^{23}$ Takve su okolnosti proizvele tzv. regulatorno natjecanje između zemalja članica koje su težile postati privlačni investicijski ciljevi.

22 U predmetu Centros (9. III. 1999. - C-212/97, European Court Reports 1999, p. 1459.) odlučivalo se o upisu društva osnovanog u Ujedinjenom Kraljevstvu u danski sudski registar. Odredbe primarnog europskog prava o slobodi poslovnog nastana protumačene su u skladu s teorijom osnivanja, pa se pravna osoba valjano osnovana u jednoj od država članica Europske unije mora priznati, odnosno upisati u relevantni registar u svim drugim državama članicama. Navedena sloboda osnivanja i djelovanja trgovačkih društava diljem Europske unije potvrđena je i u presudama Überseering (5. XI. 2002. C-108/00, European Court Reports 2002, p. 9919.) i Inspire Art (30. IX. 2003. - C-167/01, European Court Reports 2005, p. 10155.). Sud Europske unije dosljedno je potvrdio nespojivost teorije stvarnog sjedišta sa slobodom poslovnog nastana i djelovanja društava u svim državama članicama Europske unije. Ne samo da se priznaje pravna i poslovna sposobnost pri prijenosu stvarnog sjedišta unutar Europske unije, već se i državi u kojoj društvo iz druge države članice želi osnovati svoju podružnicu zabranilo nametanje otegotnih nacionalnih pravnih propisa. Više o tome v. Lutter, M., Bayer W., Schmidt, J., Europäische Unternehmes- und Kapitalmarktrecht, 6. Aufl. 2018, § 7 Rz. 7.19., a za naše pravo v. Bouček, V., „Osobni statut trgovačkog društva i specifičnih europskih trgovačkih društava u europskom međunarodnom privatnom pravu“, Zbornik Pravnog fakulteta Sveučilišta u Zagrebu, vol. 56. (2006.), str. 129. i dalje. Jurić, D., „Prekogranični prijenos sjedišta trgovačkog društva u europskom i hrvatskom pravu“, Zbornik Pravnog fakulteta Sveučilišta u Zagrebu, vol. 66. (2016.), str. 735. i dalje.

${ }^{23}$ U prvom desetljeću dvadeset i prvog stoljeća dogodio se tzv. Limited boom, pa je primjerice u njemačkoj literaturi naveden podatak da je između 2003. i 2008. čak $25 \%$ novoosnovanih društava kapitala koja posluju u Njemačkoj osnovano u Ujedinjenom Kraljevstvu s neznatnim temeljnim kapitalom. Više o tome vidi Keiner, R., „Eine Rechtsformvariante bewegt Europa“, Zeitschrift für Gesellschaft-, Unternehmens- und Steuerrecht der GmbH und GmbH \& Co. KG, 22/18, str. 1182. Već se Companies Actom iz 1985. otklonila obveza unosa kapitala u private company limited by shares (nadalje: Limited ili LTD) da osnuju društvo s minimalno zamislivim iznosom. Novim Companies Actom iz 2006. dodatno su otklonjene administrativne prepreke, olakšalo se osnivanje LTD-a, a uvela se i mogućnost osnivanja društva elektroničkim putem bez sudjelovanja stručne osobe (javnog bilježnika). Osnivanje LTD-društva moguće je učiniti elektroničkim putem na mrežnoj stranici registra (eng. Companies House). Takvo osnivanje moguće je učiniti samo uz primjenu modela pravila društvenog ugovora (engl. model Articles of Association), kao temeljnog akta društva, te popunjavanje online prijave koja sadrži osnovne podatke o samom društvu, primjerice, podatke o sjedištu društva, informacije o tomu primjenjuju li se model pravila društvenog ugovora, informacije o imenovanim direktorima (engl. directors) i tajnicima društva (engl. company secretary), podaci o iznosu uplaćenog temeljnoga kapitala ako ga društvo ima te informacije o osnivačima i njihovim udjelima u društvu. Model pravila društvenog ugovora primjenjuje se na sva društva koja neko pitanje nisu uredila drukčije svojim društvenim ugovorom ili pri registraciji uopće nisu podnijela društveni ugovor (čl. 20. st. 1. Companies Acta). Osim toga, potrebno je sastaviti i ugovor o osnivanju društva (engl. Memorandum of Association) kojim osnivači očituju svoju volju na osnivanje društva i pristaju biti njegovi članovi (čl. 8. Companies Acta). Takav ugovor biva automatski generiran iz podataka danih u samoj prijavi pri registraciji (imena osnivača) kada je prijava osnivanja učinjena online. Prijavu nije potrebno ovjeriti kod javnog bilježnika niti naknadno potvrditi vlastoručnim potpisima osnivača odnosno direktora društva. Više o tome vidi Jakšić, T., Petrović, S., „Mogući pravci izmjena i dopuna hrvatskog prava društava“, Zbornik Pravnog fakulteta Sveučilišta u Rijeci, vol. 37., 3/16, str. 1107. 
Ne samo zbog unutarnjih pravnih i gospodarskih potreba poboljšanja poslovanja, već i radi konkurentnosti nacionalnog gospodarstva, prionulo se reformama, u prvom redu prava društava. Temeljni pravnopolitički ciljevi koji su potakli izmjene i dopune nacionalnog prava društava mogli bi se svesti na jednoobraznu sintagmu: ,jednostavno, jeftino, brzo i po mogućnosti elektroničkim putem“. ${ }^{24}$ Nakon britanskog ,udara“ na njemački najvažniji pravni izvozni proizvod - društvo s ograničenom odgovornošću, uslijedio je odgovor u vidu Zakona o modernizaciji prava društava s ograničenom odgovornošću i suzbijanju zlouporaba..$^{25}$ Tragalo se za modelom kojim bi se osujetio „ulazak“ britanskih društava koje osnivaju njemački poduzetnici u njemačko gospodarstvo, odnosno koji bi dotadašnju praksu učinio neprivlačnom. U doktrinarnom prijeporu je li svrsishodnije u pravni poredak unijeti novi oblik trgovačkog društva kapitala ili preurediti postojeće društvo s ograničenom odgovornošću, izabralo se drugo rješenje. Osmislila se posebna vrsta d.o.o.-a koje se može osnovati s ulogom od jednog eura. Zbog izvorne potkapitaliziranosti i sumnje u financijsku potentnost društvo u pravnome prometu ne smije koristiti punu ili skraćenu naznaku oblika društva - GmbH, već se naznaka oblika unutar tvrtke mora nasloviti kao ,podzetničko društvo“" (njem. Unternehmengeselschaft ili $U G$ Haftungsbeschränkt). To društvo uređeno je § 5a navedenog zakona, za koji se ne može samo kazati da je uzor za izradu čl. 390.a ZTD-a, već je gotovo doslovno, s minimalnim izmjenama preuzet u naš pravni poredak Novelom ZTD-a 2012. Vanjski su razlozi prouzročili značajan pad novoosnovanih $\mathrm{GmbH}-a$ i recipročni porast, gotovo invaziju, Limiteda, što je njemačkog zakonodavaca ponukalo da se upustiti u regulatorno natjecanje na području Prava društava. Je li se u Republici Hrvatskoj pojavio pritisak stranih trgovačkih društava, i zbog toga za četvrtinu smanjio broj novoosnovanih d.o.o.-a.? Je li nužno smanjiti migraciju hrvatskih poduzetnika? Je li ona uopće postoji? Negativan odgovor na navedena pitanja potkopava opravdanost nekritičkog preuzimanja pravnih rješenja, makar se radilo o onima iz prava uzora. Naš je problem više unutarnje nego vanjske prirode, pa se sukladno tomu trebaju definirati pravnopolitički ciljevi koji se izmjenama i dopunama zakona žele postići. $\mathrm{Na}$ njih primarno moraju utjecati potrebe nacionalnog gospodarstva i poduzetnika, a regulatorno natjecanje bi trebalo samo osluškivati, i po potrebi reagirati, a ne biti njegov prominentni sudionik. U suvremenom dinamičnom razvoju Prava društava dobro je slijediti pravo uzor, ali ne slijepo i nekritički, već odabirati samo ona pravna rješenja koja pospješuju naš pravni i gospodarski sustav.

Jednostavno društvo s ograničenom odgovornošću u naš pravni sustav uvedeno je radi ubrzanja postupka osnivanja, olakšanja upuštanja u poduzetnički pothvat, smanjenja troškova osnivanja, sprečavanja obavljanja neregistrirane djelatnosti i smanjenja migracije hrvatskih poduzetnika. ${ }^{26}$ Dvojbe oko pitanja je li uvođenje

24 To se uočava u Nacrtu prijedloga Zakona o izmjenama i dopunama ZTD-a od 8. ožujka 2019. Za Veliku Britaniju, Nizozemsku i Francusku vidi ibidem str. 1106. i dalje.

25 Gesetz zur Modenisirung des GmbH-Rechts und zur Bekämpfung von Missbräuchen (nadalje: MoMiG) usvojen je u Bundestagu 28. lipnja 2008.

26 Razlozi su navedeni u Nacrtu prijedloga Novele u 2012., od svibnja 2012. Više o tome v. https// www.vlada.gov.hr. Stranica pregledana 10. listopada 2019. 
„njemačkog modela“ najbolji način da se ostvare navedeni ciljevi, kao i opravdanost povećanja broja osnivača j.d.o.o.-a koja se propisala Novelom u 2019., razriješit će se nakon raščlambe navedenog instituta.

\subsubsection{Differentia specifica j.d.o.o.-a u odnosu na ,klasični“ d.o.o.}

Kao podvrsta ili njegova inačica j.d.o.o. se od „klasičnog“ d.o.o.-a razlikuje po obilježjima koja su prisilnim odredbama utvrđena u čl. 390.a ZTD-a. Temeljni kapital društva iznosi između 10 kn i 19.999 kn, a najniži nominalni iznos poslovnog udjela jest jedna kuna. Ulozi ne moraju biti jednaki, ali se ne može kao kod osnivanja d.o.o.-a preuzeti više poslovnih udjela. Prije upisa društva u sudski registar, moraju se uplatiti ulozi za sve preuzete poslovne udjele i to samo u novcu. Društvo mora oformiti posebne zakonske rezerve za točno propisane svrhe, pa je stroži režim popunjavanja zakonskih rezervi. Prijeti li društvu nesposobnost za plaćanje, mora se odmah sazvati skupština društva. Posebnost se toga društva mora deklarirati u pravnom prometu tako da se u naznaci pravnog oblika društva unutar tvrtke mora navesti ,jednostavno društvo s ograničenom odgovornošću“ (ili kratica j.d.o.o.). Društvo može osnovati najviše pet članova, a uprava se sastoji od jednog člana direktora, ne može imati nadzorni odbor.

Pojednostavljeni način njegova osnivanja obvezuje osnivače da koriste obrasce zapisnika čiji je sadržaj kao zakonski prilog unaprijed određen. ${ }^{27}$ Izjavu o osnivanju j.d.o.o.-a ili društveni ugovor (ako društvo ima između dva i pet osnivača) nije dopušteno sadržajno umanjivati ili proširivati. Nedostatak prilagodljivosti i krutost u unutarnjem uređenju odnosa u društvu, koja nije svojstvena dogmatici d.o.o.-a, osnivači olako previđaju ili možda zanemaruju. Temeljni je razlog tomu što osnivače neodoljivo privlači činjenica da mogu osnovati društvo kapitala bez spomena vrijednog unosa kapitala. Na vjetrometini budućih poslovnih aktivnosti j.d.o.o.-a članovi društva zaštićeni su od „,bočnih udara“ odnosno zahtjeva vjerovnika da ispune obvezu društva. Prisilnom odredbom čl. 10. st. 2. ZTD-a utvrđena neodgovornost članova društava kapitala za obveze društva štiti savjesne članove. Izuzetno, ako vjerovnici dokažu da se zlorabila okolnost neodgovornosti za obveze društva, moguće je „,zadirati“ u imovinu članova. ${ }^{28} \mathrm{Je}$ li ispravno osloboditi članove j.d.o.o.-a unošenja uloga u društvo i istovremeno im osigurati povlasticu neodgovornosti za obveze društva? Naime, ne može se reći da obveza od minimalnog unosa od 1 kune utječe na stvaranje početnog kapitala. Ako društvo nije opremljeno kapitalom za obavljanje nakanjenih djelatnosti, a istovremeno opstanu sve povlastice koje uživaju članovi društva kapitala, otvorenim ostaje pitanje kako će se štititi vjerovnici društva. U tomu su slučaju u nezavidnom položaju koji je tegobniji od položaja članova svih drugih trgovačkih društava. Naime, članovi društva kapitala uživaju povlasticu neodgovornosti za obveze, ali moraju unijeti određeni kapital u društvo, bilo da

27 Čl. 390.a st. 1. ZTD-a. U prilogu ZTD-a navedeni obrasci su naslovljeni: „Obrazac izjave o osnivanju j.d.o.o.-a“ i ,,Obrazac društvenog ugovora j.d.o.o.-a“”.

${ }_{28}$ Tako vidi odredbu čl. 10. st. 3. i 4. ZTD-a. O proboju odgovornosti kod društava kapitala vidi Barbić, J., Pravo društava, Knjiga prva, Opći dio, 2. izd., str. 296. i dalje. 
na društvo prenose pravo vlasništva nad novcem ili stvarima, bilo da prestaju biti imatelji prava koje prenose na društvo. S druge strane, članovi javnog trgovačkog društva i komplementari u komanditnome društvu nemaju obvezu unosa kapitala u društvo, ali odgovaraju za obveze društva osobno, solidarno i neograničeno cijelom svojom imovinom. ${ }^{29}$

J.d.o.o. može nastati samo osnivanjem, a isključena je mogućnost njegova nastanka statusnom promjenom: preoblikovanjem, spajanjem ili podjelom društava. ${ }^{30}$ Postojeći d.o.o. ne može smanjenjem temeljnog kapitala „prijeći“ u j.d.o.o. A contrario, koncept j.d.o.o.-a zamišljen je kao prijelazni oblik prema „pravom“ d.o.o.-u, a put je jednosmjeran, jer samo povećanjem temeljnog kapitala na iznos od 20.000 kuna ili više to društvo postaje d.o.o. ${ }^{31}$ Ta „,prirodna“ težnja ka kapitalnom osnaživanju društva poduprta strožim režimom popunjavanja zakonskih rezervi ne mora se nikada ostvariti tako da društvo trajno može poslovati kao j.d.o.o. Članovi nisu obvezni donijeti odluku o povećanju temeljnog kapitala iz sredstava društva iako iznos kapitalnih rezervi premašuje 20.000 kuna.

\subsubsection{Načelo unosa i održanja kapitala u službi zaštite vjerovnika}

Najvažniji, a ako ne i jedini razlozi, zbog kojih se osnivači odlučuju za osnivanje društva na pojednostavljeni način jesu niži troškovi osnivanja i mizeran iznos temeljnog kapitala. ${ }^{32}$ J.d.o.o. je zadržao kategoriju temeljnog kapitala u iznosu koji može biti 10 kuna. Jasno je da se tu ne radi o garancijskoj funkciji temeljnog kapitala. Načelno temeljni kapital služi kao znak da je u određenom trenutku određena imovina unesena u društvo na ime uplate uloga u društvo (pri osnivanju su bile unesene najmanje vrijednosti koje odgovaraju iznosu tog kapitala) odnosno kako društvo prema članu ima određenu tražbinu s naslova uplate takvog uloga u društvo ako on ranije nije bio uplaćen.$^{33}$ Kako je temeljni kapital računovodstvena kategorija i ulazi u pasivu društva, tim se kapitalom ne odgovara za obveze. ${ }^{34} \mathrm{Za}$ sigurnost vjerovnika bitna je imovina društva koja čini njegovu aktivu i kojom društvo odgovara za svoje obveze. Dva su temeljna načela na temelju kojih se

29 Vidi odredbu čl. 10. st. 1. ZTD-a.

30 Statusnom promjenom pripajanja društvo preuzimatelj ostaje, a pripojeno društvo prestaje postojati, pa se niti teorijski ne može dogoditi da nastane novo društvo.

31 Više o tome vidi Barbić, J., Pravo društava, Knjiga druga, Društva kapitala, Svezak II, Društvo s ograničenom odgovornošću, Društvo za uzajamno osiguranje, Kreditna unija, Europsko društvo Societas Europea (SE), 6. izd., str. 598. i dalje.

32 Radi tako minimalnog malog iznosa temeljnog kapitala (10 kn) u našoj praksi se j.d.o.o. pejorativno i u šali naziva ,jado“. U Njemačkoj praksi je kratica $U G$ zadobila cinične i sarkastične prizvuke kao što su „prljavi poslovi“ (njem. Unsaubere Geschäfte) odnosno „među varalicama“ (njem. Unter Gaunern). Više o tome vidi Hennrichs, J., „Kapitalschutz bei GmbH, UG und SPE“, Neue Zeitschrift für Gesellschaftsrecht, 28/2009, str. 1164 .

33 Temeljni kapital jest u novcu izražena vrijednost onoga što članovi moraju unijeti u društvo na ime uplate dijelova tog kapitala koji se odnose na poslovne udjele. Računovodstveni pojam ,upisanog kapitala“ odgovara pojmu temeljnog kapitala i iskazuje se u pasivi društva. Više o tome vidi Barbić, J., Pravo društava, Knjiga druga, Društva kapitala, Svezak I., Dioničko društvo, 6. izd., str. 45. i dalje.

34 Društvo za svoje obveze odgovara onim što se nalazi u njegovoj aktivi, a u nju ulazi i sve što se u društvo unese na temelju uplate vrijednosti temeljnog kapitala. Tako ibidem. 
utvrđuje da društvo ima najmanje onoliku imovinu koja po vrijednosti odgovara temeljnom kapitalu, a što vjerovnicima pruža sigurnost da društvo ima čime podmiriti njihove tražbine čija vrijednost doseže iznos visine temeljnog kapitala: a) načelo unosa kapitala i b) načelo održanja kapitala. Uz navedene, instrumenti za zaštitu vjerovnika jesu pravila o transparentnosti i financijskom izvješćivanju, pravila o postupanju u krizi i opći instrumenti privatnog prava. ${ }^{35}$ Ideja zaštite vjerovnika utemeljena na zaštiti temeljnog kapitala društva u britanskomu pravu, i sustavima kojima je ono uzor, nikada nije zaživjela, a postala je potpuno anakrona činjenicom da se Limited (društvo kapitala) može osnovati za 1 funtu. ${ }^{36}$ Nedostatak obveze unosa i održanja temeljnog kapitala nadomješta se pravilima o transparentnosti i financijskom izvješćivanju i odgovornosti direktora društva.

Osnivanje, raspodjela dobiti i kriza centralne su točke zaštite vjerovnika u kojima su izravno sukobljeni interesi članova društva i vjerovnika. ${ }^{37}$ Olako ulaženje u poduzetnički pothvat, preoptimistično i rizično postupanje članova društva ne bi se trebalo prelamati ,preko leđa“ vjerovnika društva. Hoće li ceh poslovnog neuspjeha i rizika poslovanja društva u konačnici platiti njegovi članovi kroz gubitak imovine uložene u društvo ili će se on svaliti na vjerovnike društva problem je koji se rješava odredbama o zaštitnom djelovanju temeljnog kapitala. Obveza unosa vrijednosti koja odgovara iznosu utvrđenog temeljnog kapitala i prepuštanje upravi društva da raspolaže tom imovinom društva osnivače društva potiče na promišljeniju odluku o ulasku u poduzetnički pothvat. Načelo unosa kapitala preventivno štiti vjerovnike koji ne trebaju nastupom poslovnih teškoća u društvu dokazivati činjenicu jesu li članovi opskrbili društvo kapitalom koji je najmanje jednak iznosu temeljnog kapitala. Obveza je svakog osnivača da prije upisa društva u sudski registar uplati najmanje četvrtinu uloga za preuzeti poslovni udio koji uplaćuje u novcu, s tim da ukupni ulog svih uplata u novcu ne može biti manji od jedne četvrtine temeljnog kapitala, ${ }^{38}$ kako se ulog unošenjem u društvo stvari i prava mora u cijelosti unijeti $\mathrm{u}$ društvo prije upisa društva u sudski registar, ${ }^{39}$ društvo je ex ante opskrbljeno kapitalom kojim se ublažava prijeteći gubitak u poslovanju. Glavna obveza člana društva jest da uplati društvu poslovni udio što se obvezao uplatiti društvu pri osnivanju društva. Zakasni li član s tom uplatom, dužan je društvu platiti zatezne kamate, a ako nakon upozorenja ne uplati poslovni udio, može ga se isključiti

35 Tako Hennrichs, J.,„Kapitalschutz bei GmbH, UG und SPE“, Neue Zeitschrift für Gesellschaftsrecht, 28/2009, str. 1162. i dalje.

36 Više o tome vidi Höfer, C, „Flex-GmbH- eine solvenzorientierte Schwester-Rechtform für die $\mathrm{GmbH}$ ?“, Zeitschrift für Gesellschaft-, Unternehmens- und Steuerrecht der GmbH und GmbH \& Co. KG, $8 / 16$, str. 398 .

37 Ibidem, str. 399.

38 Tako čl. 390. st. 2. ZTD-a. Novelom ZTD-a u 2019. obveza ukupnog iznosa uplata u novcu, umjesto dosadašnjih 10.000 kuna, ne smije biti manja od četvrtine temeljnog kapitala. To znači da je moguće osnovati d.o.o. s ulogom od 5000 kuna. Ali ulog u novcu mora se u cijelosti unijeti u roku od godine dana od dana upisa društva u sudski registar.

39 Tako čl. 390. st. 3. ZTD-a. 
iz društva. ${ }^{40}$ Pozornošću urednog i savjesnog gospodarstvenika ${ }^{41}$ članovi uprave moraju skrbiti o obvezama uplate neuplaćenih uloga u novcu, jer se ulog unošenjem u društvo stvari i prava mora u cjelini unijeti prije upisa društva u sudski registar. ${ }^{42}$

Članovi uprave društva u izvršenju svojih poslovodnih ovlasti raspolažu imovinom društva, ali presudan utjecaj na to imaju članovi društva. ${ }^{43}$ Radi zaštite interesa vjerovnika i ostvarenja cilja društva, pravilima o održanju kapitala ograničava se članove društva da slobodno raspolažu imovinom društva. ${ }^{44}$ Nisu dopuštene isplate članovima društva iz imovine društva vrijednost koje odgovara iznosu temeljnog kapitala. ${ }^{45}$ Članovi društva mogu nedopušteno zahvatiti u imovinu društva na različite načine: izvlačenjem likvidne imovine iz društva, know-howa, ključne radne snage ili poslovnih veza u korist člana ili drugog društva nad kojim član ima kontrolu, vođenjem poslova društva s ciljem pogodovanja članu ili drugom društvu nad kojim član ima kontrolu ili nelojalnim konkuriranjem društvu. ${ }^{46}$ Posljedica nedopuštenog zahvata u imovinu društva bit će stoga umanjenje imovine društva, izostanak prihoda ili umanjenje imovine popraćeno daljnjim izostankom prihoda. ${ }^{47}$ Procjena dopuštenosti svake isplate iz imovine društva počiva na načelima unosa i održanja kapitala te na pravilima na sastavljanju izvješća o financijskom položaju društva. ${ }^{48}$ Obveza održavanja imovine društva u vrijednosti koja odgovara iznosu temeljnog kapitala, povjerena je članovima uprave, ali i članovima društva, s obzirom na njihov utjecaj na vođenje poslova. Članovi uprave društva dužni su osigurati da će u društvo biti unesena imovina na ime uplata temeljnog kapitala i dužna je štititi taj kapital. Od osnivanja do prestanka (ili stečaja) društva uprava mora čuvati taj kapital i paziti da se on na bilo koji način ne vrati članovima društva ili trećim osobama. ${ }^{49}$ Dužnost održanja kapitala, štoviše, nije ograničena samo na puko uzdržavanje od nedopuštenih isplata iz imovine društva već obuhvaća obvezu

40 Tako čl. 399. i 400. ZTD-a.

${ }^{41}$ Tako čl. 430. u svezi s čl. 252. ZTD-a.

42 Tako čl. 390. st. 3. ZTD-a.

43 Tako vidi odredbe čl. 422. st 2. , 423. st. 2., i 424. ZTD-a. Članovi društva odnosno skupština imenuju članove uprave i mogu ih opozvati u svako doba. Članovi društva mogu voditi poslove društva bilo da upravi daju upute (u obliku savjeta ili zaključka skupštine) kako postupati u određenim prilikama ili da se društvenim ugovorom odnosno izjavom o osnivanju predvidi davanje odobrenja upravi na poduzimanje određenih poslova. Više o tome vidi Baumbach, A., Hueck, A., Gesetz getreffend die Gesellschaften mit beschränkter Haftung, München, 2010., § 13, Rn. 18.

44 Pored prisilnih odredbi o održanju kapitala (čl. 407. ZTD-a) propisana je zabrana zlouporabe članskog položaja u društvu (čl. 10. st. 3. i 4. ZTD-a), a članovi društva moraju obazrivo postupati i u slučajevima zabrane iskorištavanja utjecaja u društvu (čl. 430. ZTD-a).

45 Vidi čl. 407. st. 1. ZTD-a.

${ }^{46}$ Više o tome vidi Širola, N., „Odgovornost članova društva s ograničenom odgovornošću za nedopušten zahvat u imovinu društva“, Zbornik Pravnog fakulteta Sveučilišta u Zagrebu, vol. 61. (2011.), str. 1689. i dalje.

47 Prihodi (eng. income, revenue, turnover; njem. Reinkommen, Einnahmen) su primanja fizičkih ili pravnih osoba u novcu ili novčana vrijednost izražena u robi i uslugama dobivena kao protuvrijednost za prodanu robu ili usluge, prodaju ili najam nekretnina, kamate na dane zajmove i sl. Cerovac, M., Rječnik pojmova prava i politike tržišnog natjecanja $i$ srodnih područja, Zagreb, 2004.

48 Više o tome vidi Winnefeld, R., Bilanz-Handbuch, 5. izd. 2015., § 13 Rn. 57.

49 Više o tome vidi Oppenländer, F., Trölitzsch, T., Praxisbuch der GmbH-Geschäftsführung, C. H. Bech, 2011., str. 256. i dalje. 
kontrole ostalih direktora ili ovlaštenih osoba poput prokurista ili punomoćnika društva kako oni ne bi članovima društva isplatili nešto nedopušteno. ${ }^{50}$ Uprava je dužna reagirati kada izvješće o financijskom položaju društva bude negativno i uskratiti bilo kakve isplate članovima jer bi to dodatno potkopalo imovinsku supstancu društva i položaj njegovih vjerovnika. ${ }^{51}$ Negativno izvješće o financijskom položaju društva (njem. Unterbilanz) postoji kada neto imovina društva ne doseže iznos temeljnog kapitala društva, odnosno kada društvo posluje s gubitkom što dovodi do pasivnog odnosno negativnog izvješća o financijskom položaju društva. ${ }^{52}$ Uprava je dužna bez odgađanja sazvati skupštinu društva kada ustanovi da je društvo izgubilo imovinu u vrijednosti polovine temeljnog kapitala. ${ }^{53}$ Radi zaštite društva i vjerovnika i smanjenja rizika od zapadanja u stečaj, osim te obveze članovi uprave dužni su obavijestiti članove društva o stanju poduzeća, sposobnosti i izgledima za njegovu sanaciju. ${ }^{54}$ Kako bi se spriječilo da se imovina društva smanjuje u korist njegovih članova, pored obveze člana društva na vraćanje onoga što je primio protivno odredbama ZTD-a, društvenog ugovora ili odluka društva propisana je i odgovornost članova uprave za naknadu štete društvu. ${ }^{55}$

Osnovni, u doktrini prepoznati razlozi za zadržavanje kategorije temeljnog kapitala jesu: a) početna kapitalna opskrbljenost za početak gospodarskog djelovanja društva (njem. Startausstattung), zaštita od latentne insolventnosti društva (njem. Verlustpufferfunktion) i c) funkcija ozbiljnosti odnosno promišljenog ulaska u poduzetnički pothvat (Serositätfunktion). ${ }^{56}$ Kategorija temeljnog kapitala u j.d.o.o.-u obesnažena je u potpunosti i izgubila je sve navedene funkcije. Jedini je razlog njezina postojanja da se članovima prizna onaj položaj u društvu koji odgovara omjeru nominalnih iznosa njihovih poslovnih udjela. Članska snaga se, ako se drukčije ne odredi društvenim ugovorom, zrcali u novčano izraženoj vrijednosti onoga što su članovi unijeli u društvo na ime uplate temeljnog kapitala. ${ }^{57}$

50 Ibidem.

51 Tako Saenger, I., Inhester, M., GmbH-Gesetz, Nomos, 2016., § 30 Rn 65.

52 Neto imovina (njem. Reinvermögen, Nettovermögen) razlika je aktive i obveza, rezervacija i odgođenog plaćanja troškova i prihoda budućeg razdoblja te rezerva kapitala i rezerva za vlastite poslovne udjele ako ih društvo ima. Neto imovinu ne umanjuju rezerve društva i s njima usporedive pozicije vlastitog kapitala koji se vode na strani pasive. Naime, ,pravu pasivu“ sačinjavaju rezervacije, obveze, odgođena plaćanja troškova, prihod budućeg razdoblja i rezerve što društvo mora imati po zakonu. Više o tome vidi ibidem.

53 Tako čl. 442. st. 2. ZTD-a. Društvo je izgubilo polovinu temeljnog kapitala kada neto imovina društva ne pokriva polovinu iznosa temeljnog kapitala utvrđenog u društvenom ugovoru, a za to su relevantna pravila vrednovanja iz izvješća o financijskom stanju društva.

54 Gubitak društva u visini polovine temeljnog kapitala ne mora biti utvrđen u financijskim izvješćima. U skladu s pozornošću urednog i savjesnog gospodarstvenika u vođenju poslova društva članovi uprave dužni su organizirati poduzeće tako da imaju permanentni uvid u njegov gospodarski položaj i financijske tijekove, te se pobrinuti za izradu financijskih izvješća kojima će se provjeriti financijsko i gospodarsko stanje društva. Više o tome vidi Lutter, M., Hommelhoff, P., GmbH-Gesetz Kommentar, 18. izdanje, Köln, 2012., § 49. Rn 16.

55 Tako čl. 407. st. 2. i 3. i 7. ZTD-a

56 Više o tome vidi Hennrichs, J. „Kapitalschutz bei GmbH, UG und SPE“, Neue Zeitschrift für Gesellschaftsrecht, 28/2009, str. 292. i dalje.

57 Arg. ex. čl. 398. st. 2. ZTD-a. 


\subsubsection{Mjere kojima se ublažava nedostatak zbog slobode (ne)unosa uloga u društvo}

Za j.d.o.o. je karakteristično da nije opremljeno kapitalom koji je primjeren financijskim potrebama društva i to je žarišna točka svih kritika upućenih prema tome društvu. ${ }^{58}$ Društvu koje se osniva s minimalnim temeljnim kapitalom nedostaju sredstva da uopće obavlja nakanjene djelatnosti, a kamoli da oformi imovinu koja će služiti za ispunjenje obveza prema vjerovnicima. Članovima se omogućuje da bez spomena vrijednog financijskog rizika i bez osobne odgovornosti za obveze društva sudjeluju u svim pogodnostima koje proizlaze iz članstva u društvu. To je izrazito nepovoljna okolnost za vjerovnike. Kako ne postoji obveza unosa kapitala većeg od 10 kuna, praktično više nisu niti primjenjive odredbe o održanju temeljnog kapitala niti postoji obveza na temelju koje bi uprava društva trebala sazvati skupštinu društva kada ustanovi da je društvo izgubilo imovinu u vrijednosti polovine temeljnog kapitala. Kako vlastiti kapital j.d.o.o.-a nije dostatan za obavljanje djelatnosti društva, odmah nakon njegova osnivanja društvo je potkapitalizirano (njem. Unterkapitalisierung) ${ }^{59}$ Međutim, u praksi se financijske potrebe društva pokrivaju zajmovima. Vjerovnicima se olakšava položaj zbog postojanja odredbi o zajmu koji nadomješta kapital. ${ }^{60}$ Kako je u slučaju zajma koji nadomješta kapital financijska potreba društva za kapitalom namirena, koji su doduše osigurali članovi ali u pogrešnom obliku (vanjskim kapitalom a ne unosom vlastitog kapitala društva), riječ je o formalnoj (nominalnoj) potkapitalizaciji (formallen/nominellen Unterkapitalisierung). ${ }^{61}$ Valja je razlikovati od slučajeva kada članovi uopće nisu pokrili financijske potrebe društva, tj. društvo nema nijedan izvor financiranja,

58 Više o tome vidi Herbarth, S., Fridrechson, J. U., „,10 Jahre MoMiG- Welche Impulse benötigt das GmbH-Recht heute?", Zeitschrift für Gesellschaft-, Unternehmens- und Steuerrecht der GmbH und $G m b H \&$ Co. $K G$ (nadalje: GmbHR), 21/18, str. 1175 .

59 Vlastiti kapital društva kapitala čine novac, stvari i prava koja su neposredno na raspolaganju društvu. On se sastoji od temeljnog kapitala, iskazanih rezervi društva, neraspoređene dobiti te godišnjeg viška. Temeljni je kapital onaj dio vlastitog kapitala društva koji unose članovi osnivanjem društva ili kasnijim povećanjem temeljnog kapitala. Nedovoljna opremljenost društva vlastitim kapitalom glavni je uzrok nastajanja stečajnih razloga i kod „klasičnog“ d.o.o.-a. Više o tome vidi Goette, W., Fleicher, H., Münchener kommentar zum GmbH-Gesetz, 3. Auf., 2018., § 5, Rn. 34. i Brnabić, R., Proboj pravne osobnosti i odgovornost za obveze, doktorska disertacija (neobjavljeno), Zagreb, 2010., str. 131.

60 Tako čl. 408. ZTD-a. Zabrana vraćanja članovima društva njihovih uloga obuhvaća i povratak članovima društva zajma kojim se nadomješta kapital društva u krizi. Sa zajmom su izjednačene i druge pravne radnje koje u gospodarskom smislu odgovaraju davanju zajma.

61 Formalno potkapitalizirano društo opremljeno je kapitalom, ali on nije priskrbljen samo unutarnjim već i vanjskim financiranjem, najčešće u obliku zajma. Članovi društva imaju slobodu izbora načina financiranja svojeg poduzetničkog pothvata. Radi zaštite vjerovnika društvo u krizi ne smije vraćati članovima zajam već se on prekvalificira (njem. umqualifiziret) u vlastiti kapital kojim društvo odgovara za obveze. Više o tome vidi Goette, W., Fleicher, H., Münchener kommentar zum GmbH-Gesetz, 3. Auf., 2018., § 5, Rn. 35 . 
uključujući i vanjski kapital. Tada je riječ o materijalnoj potkapitalizaciji. ${ }^{62}$ Kako vjerovnici j.d.o.o.-a ne uživaju zaštitu od raspolaganja članova imovinom društva odredbama o unosu i održanju kapitala (jer 10 kuna nije spomena vrijedan kapital koji se štiti), a članovi ne daju zajam društvu kojim se nadomješta kapital, jedina im je ,slamka spasa“ u naplati tražbine da izvrše proboj pravne osobnosti na temelju čl. 10. st. 3. i 4. ZTD-a. Opravdano je da članovi društva odgovaraju za obveze društva u slučaju materijalne potkapitalizacije, jer ulogom od 10 kuna ne mogu se osloboditi obveze da društvo opreme vanjskim kapitalom na osnovi kojeg će ono moći izvršavati svoje obveze. Ako nisu spremni financirati društvo niti unutarnjim niti vanjskim kapitalom, rizik poslovanja društva u potpunosti prevaljuju na vjerovnike društva. Takvo postupanje treba sankcionirati jednostavnim predmnijevanjem da član koji društvu ne priskrbi niti unutarnji niti vanjski kapital zloupotrebljava okolnosti da kao član društva ne odgovara za obveze društva i koristi društvo da bi oštetio vjerovnike. ${ }^{63}$

Narušavanje sustava utemeljenog na ideji kapitalno orijentirane zaštite vjerovnika zakonodavac je pokušao nadomjestiti s tri mjere: a) propisivanjem obveze stvaranja zakonskih rezervi, b) hitno sazivanje skupštine društva u krizi i c) obveza javnog legitimiranja u naznaci pravnog oblika tvrtke.

Društvo mora imati zakonske rezerve u koje mora unijeti četvrtinu iznosa dobiti društva iskazane u godišnjim financijskim izvješćima umanjene za iznos gubitka iz prethodne godine. ${ }^{64}$ Prisilna kapitalizacija (njem. Zwangsthesaurierung) društva traje sve dok se ne izvrši povećanje temeljnog kapitala iz sredstava društva na iznos koji je barem jednak minimalnom iznosu temeljnog kapitala (20.000 kn). ${ }^{65}$ Ako rezerve kapitala premaše navedeni iznos, ne prestaje obveza njihova punjenja za iznos koji odgovara četvrtini iznosa dobiti društva. Članovi društva mogu trajno zadržati „prijelazni oblik“ j.d.o.o-a jednostavno ne donoseći odluku o povećanju temeljnog kapitala iz sredstava društva, ali se tada izlažu riziku da se godinama akumulirana rezerva ,isuši“ iznenadnim gubitkom društva. Naime, društvo za obveze odgovara svojom cjelokupnom imovinom, pa tako i onom koja se stvorila akumulacijom zakonskih rezervi. Prima facie vjerovnicima društva koje

62 Društvo se smatra materijalno potkapitaliziranim ako je njegov kapital nedostatan za pokrivanje srednjoročnih ili dugoročnih financijskih obveza (a društvo ne može dobiti kredit), imajući u vidu vrstu i opseg očekivane ili stvarne poslovne aktivnosti te metode financiranja društva. Materijalna potkapitalizacija može biti početna i naknadna, jednostavna i kvalificirana. Kod početne potkapitalizacije društvo od početka nema dostatan kapital potreban za poslovanje, a u slučaju naknadne potkapitalizacije to stanje imovine društva nastaje zbog gubitka u poslovanju, širenja opsega poslovanja promjene djelatnosti te zbog izvlačenja sredstava iz imovine društva. Jednostavna potkapitalizacija razlikuje se prema opsegu potkapitaliziranosti društva, a članovima društva je jasno i vidljivo da društvo nije opremljeno kapitalom pa je opravdano očekivati da po redovnom tijeku stvari, i to s visokom vjerojatnošću, društvo neće moći ispunjavati obveze prema vjerovnicima. Pitanje potkapitalizacije smatra se središnjim problemom društava S ograničenom odgovornošću. Više o tome vidi Brnabić, R., Proboj pravne osobnosti $i$ odgovornost za obveze, doktorska disertacija (neobjavljeno), Zagreb, 2010., str. 170. i Goette, W., Fleicher, H., Münchener kommentar zum GmbH-Gesetz, 3. Auf., 2018., § 5, Rn. 36.

${ }_{63}$ Arg. ex Čl. 10. st. 3. i 4. ZTD-a. Tako sa stajališta nama u tom dijelu poredbenog njemačkog prava vidi Goette, W., Fleicher, H., Münchener kommentar zum GmbH-Gesetz, 3. Auf., 2018., § 5, Rn. 37.

${ }_{64}$ Tako čl. 390.a st. 5. ZTD-a.

65 Čl. 390.a st. 7. ZTD-a. 
ostvaruje dobit odgovara da društvo trajno ostane u obliku j.d.o.o.-a i da ne prelazi u „klasično“ d.o.o. jer stvorene rezerve kapitala u praksi bi trebale biti više od visine najnižeg iznosa propisanog temeljnog kapitala. Vjerovnicima odgovara da im dužnik ima veću imovinu. Međutim, društvo može organizirati svoje poslovanje tako da je njegova rentabilnost minimalna, odnosno da periodično zapada u gubitak koji će se sanirati iz kapitalnih rezervi. ${ }^{66}$ Zakonom su određene svrhe za koje se rezerve kapitala moraju upotrijebiti: a) povećanje temeljnog kapitala pretvaranjem rezervi u temeljni kapital društva, b) pokriće gubitka iskazanog za godinu za koju se podnose godišnja financijska izvješća, ako nije pokriven iz dobiti prethodne godine i c) pokriće gubitka iskazanog za prethodnu godinu ako taj gubitak nije pokriven iz dobiti iskazane u godišnjim financijskim izvješćima za godinu za koju se podnose ${ }^{67}$ Obvezne rezerve kapitala, međutim, ne mogu se smatrati mjerom kojom se uravnotežuje početna potkapitaliziranost društva, jer ako članovi ne osiguraju likvidni kapital zajmovima ili na neki drugi način, društvo nedugo nakon osnivanja neće moći ispunjavati svoje obveze prema vjerovnicima, a to je put u stečaj društva. Tek kada društvo u svojim financijskim izvješćima iskaže dobit počinju se ,puniti“ kapitalne rezerve i to samo za četvrtinu iskazanog iznosa dobiti. Obveza unosa i održanja kapitala štiti društvo i vjerovnike ex ante do visine određenog temeljnog kapitala, dočim obveza formiranja kapitalnih rezervi za točno određene svrhe djeluje ex post. Vjerovnicima će se olakšati položaj u budućnosti uz pretpostavku da društvo posluje s dobitkom. Zabranjena je svaka radnja kojom se umanjuje dobit kao i prikrivena raspodjela dobiti, primjerice, plaćanje visokih zakupnina, nerazmjerno visoke nagrade članovima uprave, bilo kakvo prenošenje imovine na treće osobe, a bez tržišno razmjerne protučinidbe i sl. ${ }^{68}$ Takva zabrana proizlazi i iz načela lojalnog postupanja, načela jednakog položaja članova društva i iz nadležnosti organa. ${ }^{69}$

Druga je mjera kojom se nastojalo ublažiti neravnotežu nastalu zbog praktične suspenzije odnosno mirovanja odredbi o unosu i održanju kapitala (sve dok se j.d.o.o. ne preobrazi u „klasični“ d.o.o.) sadržana u obvezi j.d.o.o.-a da u krizi sazove skupštinu društva. ${ }^{70}$ Izričaj odredbe ,prijeti li društvu nesposobnost za

66 Stjecanje dobiti najčešći je razlog zbog kojeg se osniva neko društvo kapitala, ali to nije obilježje bez kojeg ono ne može postojati. Tako se j.d.o.o. može osnovati za ostvarenje svih dopuštenih interesa članova. Tako, primjerice poslovanje ovisnih društava radi ostvarenja interesa u koncernu nema za cilj stjecanje dobiti. Više o tome vidi Barbić, J., Pravo društava, Knjiga prva, Opći dio, 3. izd., Zagreb, 2008. str. 148.

67 Tako čl. 390.a st. 5. ZTD-a.

68 Tako sa stajališta nama u tom dijelu poredbenog njemačkog prava vidi Goette, W., Fleicher, H., Münchener kommentar zum GmbH-Gesetz, 3. Auf., 2018., § 5a, Rn. 31., 32. i 33.

69 Ibidem.

70 Na temelju odredbe čl. 442. st. 2. ZTD-a, skupština se mora bez odgađanja sazvati onda kad se uoči da je društvo izgubilo polovinu temeljnog kapitala. Navedena odredba nije primjenjiva kod j.d.o.o. jer se zbog minimalnog iznosa temeljnog kapitala gubi svrha i smisao kao i kod odredbi o održanju i unosu kapitala. 
plaćanje“ ukazuje na posebnost kriznog stanja u društvu. ${ }^{71}$ Ako društvo ne može raspoloživim novcem podmiriti svoje dospjele dugove u rokovima njihova dospijeća, ono je nesposobno za plaćanje. ${ }^{72}$ Clanovi uprave pozornošću urednog i savjesnog gospodarstvenika dužni su planirati novčane tijekove u društvu i predviđati na temelju objektivnih mjerila mogućnost budućeg namirenja obveza. Ako tijek novčane mase i planirano dospijeće obveza društva nisu usklađeni, to ukazuje na moguće probleme u svezi s plaćanjem. Uprava je tada dužna odmah sazvati skupštinu društva na kojoj se trebaju rješavati problemi nadolazeće nesposobnosti za plaćanje i usvojiti odluke o protumjerama na temelju kojih bi se trebala otkloniti navedena prijeteća okolnost. De facto se time ne otklanja inicijalna potkapitaliziranost jer od svojega je osnutka j.d.o.o. u stanju prijeteće nesposobnosti za plaćanje. Ali ako osnivači, najčešće zajmovima, pribave vanjski kapital ili se stvore zalihe kapitala ili se poveća temeljni kapital, ta prijetnja se otklanja. Članovi društva moraju biti upoznati s tom činjenicom jer ona proizlazi iz poslovnog plana i cilja društva pa je sazivanje skupštine društva u praksi neučinkovito. I ova je mjera, kao i prethodno spomenuta, $\mathrm{s}$ ex post učinkom i njome se ne rješava problem inicijalne potkapitaliziranosti društva koji nastaje zbog suspenzije odredbi o unosu i održanju kapitala.

Obveza da pravni oblik tvrtke sadrži naznaku ,jednostavno“ trajne je naravi i tek kad društvo prijeđe $u$ „,klasično“ d.o.o. otpada taj dodatak. Njime se obavještava vjerovnike da imaju posla s društvom koje je, barem u početku, vjerojatno formalno ili materijalno potkapitalizirano. Taj upozoravajući i stigmatizirajući signal odaslan je vjerovnicima koji trebaju opreznije sklapati poslove i dodatnim privatnopravnim poslovima osiguravati svoje tražbine. Učinak publiciteta pomaže poslovnim partnerima da odvažu rizičnost stupanja u pravni odnos s takvim društvom, ali nema važnost ex post. Naime, kad se sklopi pravni posao, vjerovnik se ne može iz njega izvući pozivanjem na to da nije znao da društvo nije opremljeno kapitalom za poduzetnički pothvat.

Navedene premise upućuju na konkluziju da je propisivanje najnižeg iznosa temeljnog kapitala na 10 kuna obeskrijepilo odredbe o unosu i održanju temeljnog kapitala koje služe, kako inicijalnoj opskrbljenosti društva vlastitim kapitalom i uspostavljanju ravnoteže između članova društva, tako i zaštiti vjerovnika. Rušenje temeljnih stupova minuciozno usklađene arhitektonike podjele rizika između članova

71 Društvo je u krizi kada uzimanje zajma nije spojivo s načelima redovitog financiranja društva odnosno u vrijeme nesposobnosti za plaćanje ili prezaduženosti društva, zatim u vrijeme sanacije društva da bi se spriječilo nastupanje stečajnih razloga te u vrijeme kada društvo nije kreditno sposobno tako da ne bi moglo dobiti zajam pod uobičajenim tržišnim rizicima. Više o tome vidi Barbić, J., Pravo društava, Knjiga druga, Društva kapitala, Svezak II, Društvo s ograničenom odgovornošću, Društvo za uzajamno osiguranje, Kreditna unija, Europsko društvo - Societas Europea (SE), 6. izd., str. 308.

72 Društvo nije nesposobno za plaćanje ako podliježe zakonskoj ili sudskoj zabrani plaćanja kao i kada ne može ispuniti obveze koje se odnose na isporuku robe. Iako se likvidnost i sposobnost društva za plaćanje međusobno isprepliću, nužno je istaći njihove razlike. Likvidnost društva jest sposobnost njegove nenovčane imovine da se u relativno kratkom roku i bez gubitaka pretvori u gotov novac. Za razliku od likvidnosti društva koja je određena i uvjetovana odnosima stanja i kretanja nenovčane imovine, sposobnost društva za plaćanje određena je tokovima novca i novčanih ekvivalenata. Više o tome vidi Proklin, M., Zima, J., „Utjecaj likvidnosti i solventnosti za poslovanje poduzetnika“, Ekonomski vjesnik, 1/2011, str. 26. 
društva i njegovih vjerovnika nije se niti približno uspjelo sanirati niti popraviti. Jer, obveza stvaranja kapitalnih rezervi, obveza sazivanja skupštine društva kada ono zapade u krizu, kao ni obveza isticanja naziva ,jednostavno“ u tvrtki društva ne rješavaju nastali problem inicijalne potkapitaliziranosti društva i njegove financijske krize koja se može javiti odmah nakon osnivanja. Članovi j.o.o.-a trebaju biti svjesni da ulaženje u poduzetnički pothvat bez imovine (10 kuna) i bez spremnosti da se djelovanje društva financira zajmovima, odnosno da se poslovi društva osiguravaju privatnopravnim poslovima kojima se opterećuje imovina društva, ipak jest rizično. Jednostavni razlog za to proizlazi iz činjenice da su takve okolnosti gotovo školski primjer pokušaja da se svi rizici pokretanja poduzetničkog pothvata prebace na vjerovnike. Ali, pravni poredak oštećenim vjerovnicima pruža zaštitu u vidu instituta proboja pravne osobnosti. Naši bi sudovi trebali zaštititi vjerovnike takvih društva i usvajati njihove zahtjeve protiv članova društva, ako se ispune okolnosti nedovoljne opskrbe kapitalom i nespremnosti članova društva da sudjeluju vlastitim kapitalom u poslovanju društva, jer su koristili društvo da bi oštetili vjerovnike. ${ }^{73}$ Osnivačima društva nije u interesu da ih u konačnici dočeka takav račun. Naime, da su namjeravali poručiti vjerovnicima da osobno cijelom svojom imovinom „stoje“ iza obveza društva, osnovali bi javno trgovačko društvo i svjesno i stoički „stajali“ iza svake obveze društva. ${ }^{74}$

\subsubsection{Višečlani j.d.o.o. i ,prokrustovski““ oktroiran sadržaj društvenog ugovora}

Novelom ZTD-a proširuje se broj osnivača s tri na pet. ${ }^{75}$ Iz obrazloženja predlagatelja Novele nije jasan pravnopolitički razlog navedenog proširenja, a vjerojatno je rezultat zahtjeva iz poslovne prakse. ${ }^{76}$ Radi smanjenja troškova osnivanja i administrativnih zapreka propisuje se obveza da se pri osnivanju j.d.o.o.-a koriste obrasci zapisnika koje sastavlja javni bilježnik, a koji su prilozi Zakonu. Standardizirani društveni ugovor ${ }^{77}$ odnosno izjava o osnivanju sadrži odredbe o tvrtki, članovima, visini temeljnog kapitala i preuzimanju poslovnih udjela, sjedištu društva, snošenje troškova osnivanja i podatke o članovima uprave. Zasebno se popunjava odluka o predmetu poslovanja, a taj standardizirani obrazac vrijedi i kao

73 Arg. ex čl. 10. st. 3. i 4. ZTD-a.

74 Ipso lege na temelju odredbe čl. 10. st. 1. i čl. 68. ZTD-a članovi javnog trgovačkog društva odgovaraju za obveze društva osobno, solidarno i neograničeno cijelom svojom imovinom.

75 Čl. 390.a st. 1. ZTD-a.

76 Proširenje broja osnivača nikako ne bi moglo biti uzrokovano dodatnim kapitalnim potrebama društva, jer će se veći vlastiti kapital priskrbiti ulozima u „klasični“ d.o.o., a ono je vjerojatno posljedica zahtjeva iz gospodarske prakse gdje se uvidjelo da postoje „mikropoduzetnički“ pothvati u kojima želi sudjelovati četiri ili pet osnivača.

77 U njemačkoj se doktrini standandizirani društveni ugovor (njem. Musterprotokoll) označava kao strano tijelo u sustavu prava društva s ograničenom odgovornošću. Više o tome vidi Harbarth, S., Fredrichson, J. U., „Welche Impulse benötigt das GmbH-Recht heute?“, Zeitschrift für Gesellschaft-, Unternehmens- und Steuerrecht der GmbH und GmbH \& Co. KG, 21/18, str. 1178. 
popis članova društva, popis osoba ovlaštenih da vode poslove društva ${ }^{78}$ te sadrži izjavu kojom član uprave prihvaća imenovanje.

Jednom osnivaču načelno odgovaraju automatizam, lakoća, brzina i niži troškovi osnivanja koji se time postižu, međutim, nemogućnost promjene u obrascu oktroiranog sadržaja društvenog ugovora lišava dvoje ili više osnivača da koriste privilegij prilagodljivosti društva zacrtanim poslovnim planovima i ciljevima te onemogućuje uobičajeno „Zatvaranje“ d.o.o.-a koje se čini odredbama društvenog ugovora. Primjerice, to su odredbe o zabrani raspolaganja poslovnim udjelom općenito ili izvan kruga određenih osoba, vinkulaciji poslovnog udjela, pravu prvokupa i pravu prvenstva u stjecanju poslovnog udjela, propisivanje posebnog oblika za prijenos poslovnog udjela, uređenju dodatnih činidbi koje su vezane za osobnost članova, povlačenje poslovnog udjela, njegovo nasljeđivanje i sl. ${ }^{79} \mathrm{U}$ dvočlanim društvima lišava se osnivače slobode da odredbama društvenog ugovora propišu postupanja kojima se izbjegava moguća blokada društva zbog različitih stajališta članova, te se onemogućuje bilo kakvo uređenje međusobnih odnosa između članova kojim se odstupa od dispozitivnih odredbi ZTD-a. Nepovoljna je okolnost da se oktroirani sadržaj društvenog ugovora ne može mijenjati niti nadopunjavati, već se to može učiniti jedino u slučaju ,prijelaza“ j.d.o.o.-a u klasični d.o.o. Radi navedenih razloga nije dobro rješenje proširenja broja osnivača društva, a contrario, trebalo se ići u obrnutom smjeru smanjenja broja osnivača.

\subsubsection{Prijedlog de lege ferenda}

Kako je pravnopolitički cilj odredbi o osnivanju društva na pojednostavljeni način dosegnut $u$ trenutku osnivanja društva, otpadaju zakonodavni motivi i ciljevi zbog kojih se ono posebno uređuje, pa sve odredbe koje uređuju „klasični“ d.o.o. treba analogno primijeniti na j.d.o.o. ${ }^{80}$ Društvo može trajno ostati u „,pravnom odijelu“ j.d.o.o.-a, što se očituje u njegovoj tvrtki. Članovi se mogu odlučiti za prijelaz u d.o.o. tako da čekaju trenutak kad se u budućnosti natalože rezerve kapitala dostatne za povećanje kapitala iz sredstava društva, ali se mogu odlučiti i za prečicu. U bilo kojem trenutku nakon nastanka j.d.o.o-a može se izvršiti prijelaz u d.o.o. povećanjem temeljnog kapitala ulozima, kako u novcu, tako i u stvarima i pravima ${ }^{81}$ Zanimljivim se čini podatak da je u SR Njemačkoj samo šest posto $U G$-a

78 U četvrtoj rečenici čl. 390.a st. 1. ZTD-a umjesto popisa osoba ovlaštenih za vođenje poslova trebalo bi stajati popis osoba ovlaštenih za zastupanje. Naime, pored članova uprave u d.o.o.-u zbog hijerarhijskog ustroja organa na vođenje poslova društva mogu izravno utjecati i članovi društva.

79 O ograničenju članstva u društvu vidi Barbić, J., Pravo društava, Knjiga druga, Društva kapitala, Svezak II, Društvo s ograničenom odgovornošću, Društvo za uzajamno osiguranje, Kreditna unija, Europsko društvo - Societas Europea (SE), 6. izd., str. 116. i dalje.

${ }_{80}$ Usredotočeno na postizanje cilja deregulacije d.o.o.-a u njemačkom pravu, našem uzoru u uređenju j.d.o.o.-a, nije se zadiralo u druge institute prava d.o.o.-a. Tako se, primjerice, pitanja vremenskog dosega zabrane ulaganja stvari i prava, prikrivenog ulaganja stvari i prava, primjene načela unosa $i$ održanja kapitala u komanditnom društvu i koncernu i sl. trebaju rješavati primjenom odredbi i instituta prava d.o.o.-a. Tako sa stajališta nama u tom dijelu poredbenog njemačkog prava vidi Hennrichs, J., „,Kapitalschutz bei GmbH, UG und SPE“, Neue Zeitschrift für Gesellschaftsrecht, 28/2009, str. 1162.

81 Tako sa stajališta nama u tom dijelu poredbenog njemačkog prava vidi Goette, W., Fleicher, H., Münchener kommentar zum GmbH-Gesetz, 3. Auf., 2018., § 5a, Rn. 41. 
„preraslo“ u $G m b H$ putem provedenog povećanja temeljnog kapitala iz sredstava društva. ${ }^{82}$ Trebalo bi istražiti koliki je kod nas postotak „sazrijevanja“ j.d.o.o.-a. Ali i letimičnim pregledom podataka o upisu tih društava u sudski registar vidljivo je da prijelazi i nisu tako česti kako je zakonodavac očekivao. Pa je i ostvarenje pravnopolitičkog razloga osnivanja „start-up-ova“ "83 - brzi prijelaz u „klasični“ d.o.o., dovedeno u pitanje. Olakšano ulaženje u „mikropoduzetničke“ pothvate objeručke je prihvaćeno u poslovnoj praksi, ali se nije izvršila ozbiljna pravna, ekonomska i politička raščlamba negativnih učinaka koji nastaju kao posljedica djelovanja, u pravilu potkapitaliziranih, a nerijetko i materijalno potkapitaliziranih društva. Nepromišljeno i brzopleto ulaženje u poduzetnički pothvat, samo zato što je ,jeftin ulaz“, i prije nego osnivači uopće mogu opisati i prispodobiti svoju poslovnu ideju, ${ }^{84}$ uzrokuje masovne stečajeve jer takva društva ne ispunjavaju elementarne obveze urednog vođenja poslovnih knjiga i izrade financijskih izvješća. Ne samo da se izigravaju vjerovnici, već se nepotrebno opterećuje nacionalno gospodarstvo i pravosudni sustav. Naime, i sami članovi j.d.o.o.-a moraju biti svjesni činjenice da, ostvari li se okolnost materijalne potkapitalizacije društva i valjano se primijeni institut proboja pravne osobnosti, oni odgovaraju vjerovnicima društva za dug društva. Međutim, kako se ne može kazati da naši trgovački sudovi dosljedno primjenjuju taj institut, vjerovnicima društva često biva uskraćeno namirenje iz imovine članova društva. Tako se učestalo svi poduzetnički rizici s članova potkapitaliziranog društva svaljuju na vjerovnike.

Samo teorijsko održanje kategorije temeljnog kapitala, bez primjene načela unosa i održanja kapitala i bez rizika osnivača da može izgubiti ulog, urušava se potporanj uzajamno usklađenog kapitalno zaštitnog sustava kojim se minuciozno raspoređuju rizici između članova društva i vjerovnika. ${ }^{85}$ Pokušaj popravka toga sustava u vidu dužnosti formiranja rezervi kapitala ili sazivanja skupštine društva nije uspješan i ne može biti kompenzacija za obesnaživanje kategorije temeljnog kapitala jer ne rješava problem početnog nedostatka likvidne imovine.

De lege ferenda predlaže se ukinuti odredbu čl. 390.a ZTD-a i propisati primjereni rok za prijelaz postojećih j.d.o.o.-a u d.o.o., povećanjem temeljnog kapitala pretvaranjem rezervi, uplatom novca ili unosom stvari i prava. ${ }^{86}$ Naime, treba poći od pretpostavke da bi svaki osnivač ili više njih zajedno trebali osigurati

82 Više o tome vidi Goette, W., Fleicher, H., Münchener kommentar zum GmbH-Gesetz, 3. Auf., 2018, § 5a, Rn. 26.

83 Nekritički i agresivni prodor anglizama i stvaranje rogobatnih kovanica osiromašuje i izobličava standard hrvatskog književnog jezika. Ovdje se u ciničnom duhu spominje, u javnom diskursu često rabljena, oznaka za trgovačko društvo koje je „lako“ osnovati.

84 Tako sa stajališta nama u tom dijelu poredbenog njemačkog prava vidi Höfer, C., „,Flex-GmbH- eine solvenzorientierte Schwester-Rechtform für die GmbH?“, Zeitschrift für Gesellschaft-, Unternehmensund Steuerrecht der GmbH und GmbH \& Co. KG, 8/16, str. 398.

85 Ibidem, str. 400.

${ }^{86}$ To nije novi prijedlog jer se ukidanje d.o.o.-a predlagalo već 2016., ali s različitim prijedlogom rješenja. Naime, predlagalo se uopće po uzoru na nizozemski model ukinuti kategoriju temeljnog kapitala za d.o.o., a vjerovnike štititi na temelju testa pozitivne bilance i testa sposobnosti podmirenja utuživih i dospjelih tražbina u roku. O tome vidi Jakšić, T., Petrović, S., „Mogući pravci izmjena i dopuna hrvatskog prava društava“, Zbornik Pravnog fakulteta Sveučilišta u Rijeci, vol. 37., 3/16, str. 1109. 
5000 kuna i barem za početak opremiti društvo minimalnom likvidnom imovinom. To doprinosi ozbiljnosti i kvaliteti sudionika na tržištu. Ne preporuča se uvođenje solventno orijentiranog sustava zaštite vjerovnika po uzoru na britansko, belgijsko ili nizozemsko pravo gdje se umjesto kategorije temeljnog kapitala vjerovnici štite pravilima o transparentnosti i financijskom izvješćivanju. ${ }^{87}$ Osnivači društva kapitala u tim sustavima moraju angažirati stručne osobe (revizore, porezne savjetnike i sl.) koji će im prije osnutka društva izraditi financijski plan, vjerodostojnost kojeg ispituje registarski sud, a trošak izrade takvog plana nije zanemariv. Na temelju testa pozitivne bilance i testa sposobnosti namirenja utuživih i dospjelih tražbina u roku izgrađuje se sustav odgovornosti članova, a oni su uvijek solidarno odgovorni za obveze društva u slučaju materijalne potkapitalizacije..$^{88}$

Postojeći sustav kapitalno orijentirane zaštite vjerovnika u našem je pravu dobar i ne treba ga mijenjati solventno orijentiranim sustavom. U našem pravu postoje pravila o transparentnosti i financijskom izvješćivanju jer su trgovci dužni na početku svog poslovanja i za kraj svake poslovne godine sastaviti financijska izvješća (početna bilanca, bilanca) što pokazuje odnos njegove imovine i njegovih dugova, a mora se izraditi i račun dobiti i gubitka ${ }^{89}$ Ta pravila ne bi trebala biti nadomjestak za zaštitu vjerovnika utvrđen institutima unosa i održanja kapitala, a uočene nedostatke u pravu trgovačkih knjiga treba uklanjati po uzoru na njemačko pravo. ${ }^{90}$ To ne bi trebalo ugroziti položaj Republike Hrvatske na različitim izvješćima o uvjetima poslovanja. ${ }^{91}$ Odluka o ulaganju motivirana je nizom čimbenika, primjerice, stanje

87 Dva su temeljna sustava zaštite vjerovnika: a) kapitalno orijentirani sustav (njem. Kapitalorientiertes Gläubigerschutzsystem) koji su prihvatile srednjoeuropske zemlje po uzoru na njemačko pravo i b) solventno orijentiran sustav (njem. solvenzorientiertes Gläubigerschutzsystem) izvorno uspostavljen u zemljama Common law pravne tradicije, koji se proširio i na kontinentalne zemlje. Tako je, primjerice, kategorija temeljnog kapitala uklonjena iz prava društva s ograničenom odgovornošću u Francuskoj, Belgiji i Nizozemskoj. U njemačkoj doktrini vlada visok stupanj suglasnosti o nužnosti zadržavanja postojećeg sustava zaštite vjerovnika. Uočljivom se čini snažna poruka da se ne eksperimentira kategorijom temeljnog kapitala: „Ukoliko bi se kapitalno orijentirani sustav zaštite vjerovnika preko noći zamijenio solventno orijentiranim sustavom to bi se moglo usporediti s operacijom na otvorenom srcu njemačkog gospodarstva“. Više o tome vidi Höfer, C., „Flex-GmbH- eine solvenzorientierte SchwesterRechtform für die GmbH?", Zeitschrift für Gesellschaft-, Unternehmens- und Steuerrecht der GmbH und $G m b H \& C o . K G, 8 / 16$, str. 405. O različitim usporedno pravnim rješenjima vidi Knaier, R., „Eine Rechtformvariante bewegt Europa“, Zeitschrift für Gesellschaft-, Unternehmens- und Steuerrecht der $G m b H$ und $G m b H \&$ Co. KG, 22/18, str. 1181. i dalje.

88 U solventno orijentiranom sustavu zaštite vjerovnika dodatno se izoštrava odgovornost članova uprave društva u svezi s izradom financijskih izvješća, vođenjem poslovnih knjiga i sl. Više o tome vidi Höfer, C., „Flex-GmbH- eine solvenzorientierte Schwester-Rechtform für die GmbH?““, Zeitschrift für Gesellschaft-, Unternehmens- und Steuerrecht der GmbH und GmbH \& Co. KG, 8/16, str. 403. i dalje.

${ }^{89}$ Čl. 7. st. 2. Zakona o računovodstvu, Narodne novine br. 78/15, 134/15, 120/16, 116/18, vidi i sa stajališta hrvatskog prava instruktivnu odredbu § 242 st. 1. njemačkog Handelsgesetzbucha.

90 O trgovačkobilančnim problemima u hrvatskom pravnom poretku vidi Miladin, P., Markovinović, H., „Ništetnost i pobojnost utvrđenih godišnjih financijskih izvješća“, Zbornik 57. Susreta pravnika, Opatija, 2019. str. 97. do 153. De lege ferenda predlaže se opsežna izmjena odredbi ZTD-a o sastavljanju financijskih izvješća, njihovu utvrđenju, pobijanju odluke glavne skupštine u svezi s tim izvješćima i sl. Dogmatski ispravno i usklađeno sa sustavom prava društava minuciozno je sročeno jedanaest članaka koji mogu biti osnova budućeg Nacrta Novele ZTD-a.

91 Više o tome vidi, primjerice, službene statističke stranice Svjetske banke (htt://data.worldbank. org/) i službene statističke stranice Svjetskog ekonomskog foruma (htt://reports.weforum.org/). Tamo postoje kategorije koje upućuju na lakoću obavljanja gospodarske djelatnosti. 
gospodarstva, učinkovitost pravosuđa, cijena radne snage, porezna opterećenja i sl. Pritom je važna i lakoća i brzina osnivanja trgovačkih društava i pravna i ekonomska sigurnost njihova djelovanja i prestanka. Promatrano s ulagačkog motrišta, inicijalni ulog od 5000,00 kuna nikako se ne može smatrati smetnjom poduzetništvu, $a$ contrario on poduzetnički pothvat čini ozbiljnijim. Mogućnošću osnivanja društva elektroničkim putem postiže se brzina i lakoća osnivanja. Pravnopolitički razlozi brzine i lakoće osnivanja, privlačenja stranih ulagača, umanjenje nezakonitog obavljanja djelatnosti nisu uvjerljivi razlozi zbog kojih bi trebalo održati j.d.o.o. Ako se u poduzetnički pothvat želi krenuti bez likvidne imovine, postoji mogućnost poslovanja u pravnom obliku javnog trgovačkog društva ili komanditnog društva ${ }^{92} \mathrm{u}$ kojima uopće ne postoji kategorija temeljnog kapitala. Fizičke osobe zakonito mogu obavljati djelatnosti na temelju odredbi zakona o obrtu. Razlozi brzine osnivanja trgovačkog društva i lakoće obavljanja djelatnosti ne bi smjeli narušavati filigranski usklađeni sustav zaštite sudionika u pravnom prometu. Ne bi se smio rizik poslovanja pretežito prebacivati na vjerovnike. To je krivi ključ za otključavanje vrata i ne treba ga dorađivati. ${ }^{93} \mathrm{U}$ njemačkoj se doktrini uvidjelo da $U G$ - Haftungsbeschränkt nije dugoročno uspješan projekt $i$ da je to društvo preuzelo negativnu predodžbu koja se u njemačkom gospodarstvu povezuje s britanskim Limitedima koji su djelovali ili djeluju u SR Njemačkoj. ${ }^{94}$

\subsection{Osnivanje društva na daljinu bez punomoćnika}

Pri osnivanju društva s ograničenom odgovornošću, osnivači moraju osobno ili putem svojih punomoćnika potpisati ugovor koji se sklapa u obliku javnobilježničkog akta ili privatne isprave koju potvrdi javni bilježnik..$^{95} \mathrm{U}$ tome slučaju osnivačima stručnu pomoć pruža javni bilježnik i obavještava (poučava) ih o njihovim pravima i

92 U komanditnom društvu komanditori se moraju obvezati društvenim ugovorom da će u društvo unijeti neki ulog.

93 Ako se ne prihvati prijedlog ukidanja odredbi o j.d.o.o.-u, de lege ferenda ih treba izmijeniti. Alternativno, ukoliko se sveobuhvatnom pravnopolitičkom i ekonomskom raščlambom pokaže da nije oportuno ukidati „pravno ruho“ j.d.o.o.-a, predlaže se radikalno smanjenje, kako broja, tako i svojstva osnivača. Samo bi jedna fizička osoba trebala zadržati povlasticu osnivanja društva na pojednostavljen način. Ako se popune rezerve kapitala društva iznad 20.000 kuna, predlaže se da u takvom slučaju društvo mora donijeti odluku o povećanju temeljnog kapitala iz rezervi društva. Time bi se ostvarila zakonodavčeva namjera da j.d.o.o. bude prijelazni oblik prema d.o.o.-u. Za jednu fizičku osobu prikladan je obrazac izjave o osnivanju društva, a osnivaču treba prepustiti slobodu pribavljanja unutarnjeg ili vanjskog kapitala. Ali, ako društvo ne bude opremljeno kapitalom dostatnim za obavljanje djelatnosti odnosno ne može vjerovnicima ispunjavati preuzete obveze, trebalo bi sistemskim i teleološkim tumačenjem odredbi o proboju pravne osobnosti olakšati vjerovnicima zaštitu tako da jedini član društva odgovara vjerovnicima za obveze društva. Za pravne osobe treba poći od pretpostavke da mogu inicijalno osigurati 5000 kuna za poduzetničke djelatnosti u kojima se osniva društvo kćer ili je pravna osoba jedan od suosnivača novog društva, a za dvije ili više osoba, uz pretpostavku da početno ulože barem toliki iznos radi ozbiljnosti i osmišljenosti poduzetničkog pothvata, značajno je da sami ili uz stručnu pomoć prilagode sadržaj društvenog ugovora poslovnim potrebama, a contrario mogu se poslužiti ponuđenim obrascima.

94 Više o tome vidi Höfer, C., „Flex-GmbH- eine solvenzorientierte Schwester-Rechtform für die GmbH?", Zeitschrift für Gesellschaft-, Unternehmens- und Steuerrecht der GmbH und GmbH \& Co. KG, 8/16, str. 405 .

95 Čl. 387. st. 1. ZTD-a. 
dužnostima. Preventivna pravna njega (njem. vorsorgende Rechtpflege) koju pružaju javni bilježnici jedan je od uporišnih stupova hrvatskih društva kapitala. ${ }^{96}$ Značajna je novost da se u naš pravni poredak uvodi izuzetak od pravila da se trgovačko društvo ne može osnovati bez sudjelovanja javnog bilježnika. Na temelju odredbi čl. 397.a do 397.e omogućuje se osnivanje društva s ograničenom odgovornošću i jednostavnog društva s ograničenom odgovornošću bez sudjelovanja punomoćnika, javnog bilježnika ili neke druge stručne osobe. Pravnopolitički cilj ubrzanja osnivanja društava i smanjenja troškova osnivanja pokušava se ostvariti time da se osnivačima pruži izbor da: a) osnuju društvo usvajanjem konstitutivnog akta društva uz sudjelovanje javnog bilježnika ili b) to učine elektroničkim putem bez sudjelovanja stručne osobe. ${ }^{97}$ Do početka 2018. godine bilo je moguće, uz redovno, i osnivanje trgovačkog društva elektroničkim putem u četrnaest zemalja članica Europske unije. ${ }^{98}$ Njemačka i Austrija nisu u tome društvu, ali jesu neke države koje svoje pravo društava izgrađuju po uzoru na njemačko pravo, primjerice, Poljska, Estonija, Bugarska i Danska. Novelom ZTD-a Republika Hrvatska postala je petnaesta država članica u kojoj je moguce osnovati trgovačko društvo kapitala na daljinu.

D.o.o. i j.d.o.o. može se osnovati na daljinu putem internetske stranice sustava sudskog registra uz korištenje autentifikacijskog sustava koji ima značajnu, odnosno visoku sigurnost u pogledu identiteta i istovjetnosti osobe koja pristupa sustavu sudskog registra i uz korištenje obrazaca koji su prilozi Zakona. ${ }^{99}$ Sustavu se pristupa osobno, tj. mora mu pristupiti osoba koja poduzima neku radnju. Pritom nije važno hoće li joj kod toga netko stručno pomoći. Za neovlašteno pristupanje i poduzimanje

96 Služba javnih bilježnika rafinirana je, evoluirana i etablirana djelatnost koja jamči pravnu i financijsku sigurnost svim sudionicima postupaka koji se razvijaju pred njima. Više o tome vidi Dika, M., „Izvanparnična i koncijilacijska funkcija javnih bilježnika - de lege lata i de lege ferenda“, Zbornik Pravnog fakulteta Sveučilišta u Zagrebu, vol. 59. (2009.), str. 1156. i dalje. Za njemačko pravo vidi Teichman, C., „Die elektroniche Gründung von Kapitalgesellschaften“, Zeitschrift für Gesellschaft-, Unternehmens- und Steuerrecht der GmbH und GmbH \& Co. KG, 1/18, str. 14.

$97 \mathrm{Na}$ temelju tumačenja Europske komisije, elektronička procedura podrazumijeva isključivi i potpuni bežični (eng. online) pristup, bez fizičkog kontakta i slanja papira, te mora biti dostupna za državljane europskog gospodarskog prostora. U nacionalnom programu reformi za 2017. utvrđeno je da se treba donijeti novi zakonodavni okvir za osnivanje trgovačkog društva, odnosno poslovnog nastana, elektroničkim putem, bez papira, pečata i javnobilježničke ovjere. Cilj je koji se želi postići unapređenje pokretanja poslovanja, koje mora biti prilagođeno sadašnjem vremenu i novim komunikacijskim mogućnostima. Više o tome v. Obrazloženje prijedloga Zakona o izmjenama i dopunama ZTD-a., str. 4. Više o tome v. https//www.vlada.gov.hr. Stranica pregledana 10. listopada 2019. Osnivanje trgovačkog društva na daljinu bilo je moguće u Ujedinjenom Kraljevstvu i prije 2014., ali se takva mogućnost proširila i zahvatila već petnaest zemalja članica nakon što je Europska komisija u travnju 2014. objavila Prijedlog direktive o društvu s ograničenom odgovornošću s jednim članom (Societas Unius Personae (SUP) koja u odredbi čl. 14. st. 3. propisuje način osnivanja društva na daljinu. Više o tome vidi Teichman, C., „Die elektroniche Gründung von Kapitalgesellschaften“, Zeitschrift für Gesellschaft-, Unternehmens-und Steuerrecht der $\mathrm{GmbH}$ und $\mathrm{GmbH} \& \mathrm{Co} . \mathrm{KG}, 1 / 18$, str. 4.

98 Više o tome vidi ibidem, str. 5.

99 Čl. 397.a st. 1. ZTD-a. U čl. 397.b st. 1. i 2. ZTD-a navode se obrasci koji se trebaju koristiti i isprave koje se treba priložiti. Odredbom čl. 52.a st. 1. ZSR-a propisano je da se prijava podnosi isključivo elektroničkim putem preko internetske stranice sudskog registra ili preko internetske stranice sudskog registra u sklopu sustava START. Postupak osnivanja društva i dalje se može provesti korištenjem usluga servisa HITRO.HR. 
radnji u sustavu predviđa se kažnjavanje za kazneno djelo računovodstvenog krivotvorenja i kazneno djelo prijevare u skladu s Kaznenim zakonom. ${ }^{100}$ Društvo se osniva na daljinu sklapanjem društvenog ugovora koji više osnivača sklapa prihvaćanjem popunjenog obrasca društvenog ugovora, a ako to čini jedan osnivač, prihvaćanjem popunjenog obrasca izjave o osnivanju društva. ${ }^{101}$ Osnivači društva mogu biti samo osobe koji imaju valjanu vjerodajnicu na temelju koje se može pristupiti sustavu sudskog registra, ako potvrde da su podaci kojima su se prijavili u sustav točni i potpuni, odnosno da se nisu naknadno izmijenili. ${ }^{102}$ Ulog se uplaćuje samo u novcu, a svaki osnivač mora uplatiti najmanje jednu četvrtinu svog uloga za preuzeti poslovni udio. ${ }^{103}$ Prijava za upis osnivanja društva na daljinu sadrži zahtjev za upis i podatke iz odredbe čl. 394. st. 4. ZTD-a. ${ }^{104}$ Sigurnosna razina za pristup sustavu trebala bi biti osigurana Pravilnikom o poduzimanju radnji u postupku osnivanja trgovačkih društava na daljinu. ${ }^{105}$

Da bi se omogućio takav način osnivanja društva, moralo se izmijeniti Zakon o sudskom registru i njegove odredbe prilagoditi novim potrebama. ${ }^{106}$ Kada se osniva d.o.o. ili j.d.o.o. na daljinu bez punomoćnika, prijava za upis podnosi se isključivo elektroničkim putem preko internetske stranice sudskog registra ili preko internetske stranice sudskog registra u sklopu sustava START. ${ }^{107}$

Zbog nužnog korištenja unaprijed formuliranih obrazaca, autonomija osnivača praktički se svodi na odabir obrasca, a predloženi obvezni sastojci društvenog ugovora, odnosno izjave o osnivanju jesu materijalne prirode i formalni sastojci su isključeni. Moguće je naknadno u društveni ugovor unijeti neki formalni sastojak i odstupiti od dispozitivnih zakonskih rješenja samo uz sudjelovanje javnog bilježnika.

100 Čl. 397.a st. 4. ZTD-a.

101 Čl. 397.c st. 1. i 2. ZTD-a. Prijavu za upis osnivanja dužni su potvrditi svi članovi uprave društva, a ona je potvrđena kada sustav sudskog registra zabilježi da su osnivači društva i članovi uprave potvrdili prijavu za upis osnivanja, a kao dan potvrde uzima se dan kada je zabilježena posljednja potvrda prihvaćanja. Odredbom čl. 52.a st. 2. ZSR-a propisuje se da prihvaćanjem osnivačkog akta svaki od osnivača potvrđuje da je suglasan s time da se njegovi osobni podaci koriste i obrađuju u postupku osnivanja društva. O pokretanju postupka i ispitivanju prijave za upis v. čl. 52.b i 52.c ZSR-a.

102 Čl. 397.d ZTD-a.

103 Čl. 397.e st. 1., 2. i 3. ZTD-a. Ulog se uplaćuje na prolazni račun osnivača kod Financijske agencije koja o tome izdaje potvrdu registarskom sudu prije upisa u sudski registar.

104 Prijavi se prilažu: primjerak društvenog ugovora odnosno izjave o osnivanju društva sa svim prilozima, popis članova osnivača s njihovim identifikacijskim podacima, iznos temeljnog kapitala rednih brojeva i nominalnih iznosa preuzetih poslovnih udjela osnivača, odluka o imenovanju i popis osoba ovlaštenih voditi poslove društva, izjava članova uprave da su upoznati s obvezom izvješćivanja suda i da ne postoje zakonom propisane okolnosti zbog kojih ne mogu biti imenovani za člana uprave, odluka o odabiru poslovne adrese i odluka u utvrđenju predmeta poslovanja društva. Navedene odluke sadržane su u obrascima koji su kao prilozi Zakona ponuđeni osnivačima društva na daljinu.

105 Pravilnik o poduzimanju radnji u postupku osnivanja trgovačkih društava na daljinu, Narodne novine br. 65/2019, stupio je na snagu 15. srpnja 2019. Odredbom čl. 3. navedenog Pravilnika propisuje se da se postupak osnivanja trgovačkog društva na daljinu provodi putem informacijskog sustava dostupnog na internetskim stranicama sudskog registra ili putem jedinstvenog informacijskog sustava uspostavljenog za pokretanje poslovanja (sustav START).

106 To je učinjeno Novelom ZSR-a na način da se dodao novi odjeljak 1.a s člancima 52.a do 52.f.

107 Čl. 52.a Zakona o sudskom registru i čl. 3. Pravilnika o poduzimanju radnji u postupku osnivanja trgovačkih društava na daljinu. 
Ako se poslovni pothvat želi prilagoditi zahtjevima osnivača i u društveni ugovor unijeti neke materijalne sastojke kojima se posebno uređuju unutarnji odnosi u društvu, osnivanje je društva na daljinu bez punomoćnika isključeno. Razlog tomu je potpuna standardizacija i obveza korištenja samo unaprijed zadanih obrazaca i priloga. Ako se u budućnosti želi izmijeniti bilo koja odredba društvenog ugovora, ili unijeti nova, to je moguće učiniti samo uz sudjelovanje javnog bilježnika. Zbog toga se može preporučiti „klasičan način“ osnivanja društva jer se u samo jednom dolasku javnom bilježniku može postići upis društva za nekoliko dana. ${ }^{108}$ To je ujedno jamstvo za primjenu propisa o sprečavanju pranja novca, a to pitanje nije riješeno navedenim odredbama osnivanja društva na daljinu. Naime, naizgled otvorenim ostaje pitanje je li pokoji dan dobitka u vremenu osnivanja društva značajniji od pravne sigurnosti koja se dovodi u pitanje zbog nesudjelovanja stručnih osoba i otvorenog pitanja primjene odredbi o sprečavanju pranja novca. Zasigurno nema dvojbe da je pravna sigurnost vrhovna vrijednost koju se ne bi smjelo žrtvovati zahtjevu da se neznatno ubrza osnivanje društva s ograničenom odgovornošću.

Odluče li se osnivači koji nisu dovoljno upućeni u navedenu materiju ${ }^{109}$ osnovati društvo elektroničkim putem, mogu brzopleto osnovati društvo i zapasti u probleme koje će rješavati uz pomoć stručnih osoba, a to će uzrokovati u pravilu veće troškove nego li je trošak usluge javnog bilježnika pri osnivanju društva. Opravdanim se čini propitati valjanost pravnopolitičkih razloga za uvođenje navedenih odredbi u naš pravni poredak. Zar se po pitanju osnivanja d.o.o.-a elektroničkim putem nije trebalo ugledati na njemačko i austrijsko pravo koji su nama uzor, kako za pravo trgovačkih društava, tako i za javnobilježničko pravo, i ne isključivati javne bilježnike iz „kritične“ faze osnivanja društva? Naime, još 2005. godine postoji ured HITRO.HR, koji je omogućio elektronički način osnivanja trgovačkih društava. Za podnošenje elektroničke prijave za upis osnivanja trgovačkog društva traži posredovanje javnog bilježnika ili ureda HITRO.HR, pa se nije pružala mogućnost neposrednog elektroničkog osnivanja. ${ }^{110}$ Ali, javni bilježnici već mogu komunicirati $\mathrm{s}$ registarskim sudom i elektroničkim putem te su ovlašteni podnositi prijave za upis u registar elektroničkim putem i izdavati izvatke, preslike i prijepise na zahtjev pravnih subjekata, tj. oni imaju iste ovlasti i obveze kao ovlašteni sudski službenici. ${ }^{111}$ Elektroničkim putem uz primjenu naprednog elektroničkog potpisa,

108 Odmah po potpisu nužne dokumentacije za osnivanje društva, javnom se bilježniku uplaćuje u depozit iznos potreban za uplatu poslovnog udjela, a on kao punomoćnik osnivača dogovara otvaranje žiroračuna društva kod banke i na njega uplaćuje ono što se uplaćuje pri osnivanju društva.

109 Djelovanja trgovačkog društva iziskuje troškove koji su povezani s otvaranjem žiro-računa, vođenjem poslovnih knjiga, utvrđivanja i objavljivanja financijskih izvješća, postupkom likvidacije društva i sl.

110 Ured HITRO. HR samo posreduje između osnivača trgovačkog društva i sudskog registra, a osnivači određene radnje moraju osobno poduzeti kod javnog bilježnika. Prijava za upis u sudski registar podnosi se sudu u obliku javno ovjerene isprave ili elektroničke prijave i elektroničkog podneska podnesenog sudu od javnog bilježnika ili ureda HITRO:HR. Elektronička prijava ili podnesak potpisan naprednim elektroničkim potpisom javnog bilježnika smatra se javno ovjerovljenom ispravom. Elektronički preko sustava e-Tvrtka, može se podnijeti prijava za rezervaciju imena ili naziva, a za d.o.o. prijava za upis osnivanja ako je ulog u novcu (čl. 39. Zakona o sudskom registru).

111 Arg. ex čl. 5. Zakona o sudskom registru. 
javni bilježnici sami ili u suradnji sa servisom HITRO.HR i trgovačkim sudovima mogli su i prije stupanja na snagu Novele ZTD-a jednostavno i brzo, u roku od jednog ili dva dana, sudjelovati u osnivanju d.o.o.-a i j.d.o.o.-a. Pri tome su se, inter alia, brinuli o istinitosti identiteta osnivača i priloženih isprava, pa su bili jamci sigurnosti pravnog poretka. Radi ostvarenja pune pravne sigurnosti, iz sustava osnivanja društva na daljinu nije se trebalo isključiti javnog bilježnika kao stručnu osobu koja, ne samo da vrši provjeru identiteta osnivača, već ih i pravno informira o temeljnim pravima i obvezama u trgovačkom društvu. ${ }^{112}$ Djelovanje javnih bilježnika zalog je pravnoj sigurnosti i brana je povredama odredbi o pranju novca i računalnim prijevarama koje su se u velikoj mjeri događale zemljama članicama Europske unije. ${ }^{113}$ Zbog toga se de lege ferenda predlaže ponovno redefiniranje odredbi o osnivanju društva na daljinu na način da se javnim bilježnicima vrati uloga koju imaju prilikom „klasičnog“ osnivanja društva. Treba se osvrnuti na rješenja koja su prokušana u njemačkom pravu gdje se sudski registar vodi isključivo u elektroničkom obliku uz sudjelovanje javnih bilježnika koji svu dokumentaciju dostavljaju sudu na elektroničkim obrascima. ${ }^{114}$ Poželjno bi bilo omogućiti izravno komuniciranje osnivača društva i javnog bilježnika putem, primjerice, video-linka, tako da se društvo i nadalje može osnovati na daljinu bez obveze fizičke nazočnosti osnivača u uredu javnog bilježnika. Takav sustav osnivanja na daljinu uz „virtualnu“ nazočnost javnog bilježnika trebale bi koristiti samo fizičke osobe, a ne i pravne osobe, radi sprečavanja računalnog kriminaliteta. Nužnost sudjelovanja javnog bilježnika, odnosno njegov ponovni povratak, u postupku osnivanja trgovačkih društava nije suprotan europskim zahtjevima za stvaranje „digitalnog unutarnjeg tržišta“" predviđenih Company Law Packageom. ${ }^{115}$

112 Osnivači koji nisu dovoljno stručno obaviješteni o djelovanju društva izlažu se opasnosti koje ih mogu spopasti brzopletim ulaskom u pothvat. Zbog toga se moraju razjasniti, primjerice, pitanja o vođenju poslovnih knjiga, utvrđivanju i objavljivanju financijskih izvješća, propisanim rezervama, o odgovornosti za obveze društva u slučaju proboja pravne osobnosti, složenosti likvidacije i sl. Više o tome vidi Barbić, J., „Novela Zakona o trgovačkim društvima u 2019.“, Zbornik 57. susreta pravnika, Opatija 2019., str. 49.

113 Posebno se ističe primjer Bugarske gdje su se nakon uvođenja mogućnosti osnivanja trgovačkih društava na daljinu dogodile masovne krađe identiteta i bilo je preko 400.000 slučajeva krivotvorenja koji su se provodili putem lažnih dokumenata i izdanih elektroničkih potpisa. Uvođenjem elektroničkog sustava osnažio se računalni kriminalitet koji se odrazio na pravosudni sustav te na gospodarsku $i$ sigurnosnu sliku države. Bugarska je 30. prosinca 2016. izmijenila relevantne propise i ponovno utvrdila isključivu nadležnost javnih bilježnika i to ne kao ovjerovitelja potpisa stranaka, već kao sastavljača isprava, odnosno potvrđivanja njihova sadržaja. Više o tome vidi Grbac, A., Grbac, M., ,Javni bilježnik i elektroničko osnivanje društava s ograničenom odgovornošću“, Javni bilježnik, Vol XXI (2017.) 44, str. 22. I Velika Britanija se nakon uvođenja mogućnosti elektroničkog osnivanja trgovačkih društva suočila s porastom tzv. Corporate Identity Fraud. Više o tome vidi Teichman, C., „,Die elektroniche Gründung von Kapitalgesellschaften“, Zeitschrift für Gesellschaft-, Unternehmens- und Steuerrecht der GmbH und GmbH \& Co. $K G, 1 / 18$, str. 14.

114 Više o njemačkom sustavu osnivanja trgovačkih društava vidi ibidem, str. 2. i dalje.

115 Više o tome vidi Knaier, R., „Digital first, Bedenken second?“, Zeitschrift für Gesellschaft-, Unternehmens- und Steuerrecht der GmbH und GmbH \& Co. KG, 11/18, str. 560. i dalje. 


\subsection{Raspolaganje poslovnim udjelom}

Novelom ZTD-a izmijenjena je odredba o načinu prijenosa poslovnog udjela. ${ }^{116}$ De facto se radi o dvije dopune odredbe čl. 412. st. 3. ZTD-a. Uz ugovor sklopljen u obliku javnobilježničkog akta i privatnu ispravu koju potvrdi javni bilježnik, kao način prijenosa poslovnog udjela dodana je odluka suda koja zamjenjuje takav ugovor. Riječ je o ugovoru koji je ishođen sudskim putem i dobro je rješenje da se on pridodao već postojećim načinima prijenosa poslovnog udjela. Važnija je druga dopuna po kojoj se nedostatak propisanog oblika ugovora kojim se preuzima obveza da će se prenijeti poslovni udio otklanja sklapanjem ugovora o prijenosu poslovnog udjela u obliku javnobilježničkog akta ili privatne potvrde koju potvrdi javni bilježnik. ${ }^{117}$

Pored navedenih promjena koje se tiču načina prijenosa poslovnog udjela, značajna je promjena nastala i u pogledu njegova zalaganja. ${ }^{118}$ Izmjenom se uskladilo pravilo o zalaganju s odredbom čl. 310. st. 1. Zakona o vlasništvu i drugim stvarnim pravima ${ }^{119}$ po kojoj je za zasnivanje založnog prava na pravu potrebno učiniti ono što i za prijenos prava na kojemu se ono zasniva, ako se zakonom ne propisuje što drugo. Kako je pravilo o zalaganju poslovnog udjela značajno odudaralo od načina na koji se on prenosi, načinjena izmjena odredbe čl. 412. st. 6. bila je nužna. Otpala je mogućnost zasnivanja neformalnom izjavom o zalaganju jer se „ugovor o davanju

116 Članstvo u društvu može se slobodno prenositi, a kako je ono utjelovljeno u poslovnom udjelu, prijenos članstva ostvaruje se pravnim poslom prijenosa poslovnog udjela. Treba razlikovati obveznopravni posao kojim se preuzima obveza prijenosa poslovnog udjela od stvarnopravnog posla kojim se poslovni udio prenosi. Ta dva pravna posla najčešće se sklapaju odvojeno, ali mogu se sklopiti i istodobno, tj. $\mathrm{u}$ istoj ispravi, pa na prvi pogled izgleda kao da je riječ o jednom pravnom poslu. Više o tome vidi Barbić, J., Pravo društava, Knjiga druga, Društva kapitala, Svezak II, Društvo s ograničenom odgovornošću, Društvo za uzajamno osiguranje, Kreditna unija, Europsko društvo - Societas Europea (SE), 6. izd., str. 108. i dalje.

117 Poslovni udio prenosi se ustupom. Pri tome treba razlikovati dva pravna posla. Jedan je obveznopravni posao kojim se preuzima obveza prijenosa poslovnog udjela, a drugi je pravni posao kojim se prenosi poslovni udio. Više o tome vidi ibidem.

118 Jedna od podvrsta založnog prava, prema predmetu zaloga, jest založno pravo na pravu. Na pravni pojam prava treba gledati kao na pojedinačno subjektivno imovinsko pravo koje je prometno i prikladno da vjerovnik iz njega namiri svoju tražbinu, ako zakonom nije drugačije određeno. Na temelju čl. 4. st. 2. Ovršnog zakona (Narodne novine br. 112/12, 25/13, 93/14, 55/16, 73/17) prava su predmet ovrhe jednako kao i stvari. Pravna esencija stvarnopravnosti jest u tome da zalogoprimac ima pravo na osiguranje, i u slučaju ispunjenja uvjeta iz založnog ugovora, pravo na namirenje iz predmeta založnog prava. Pored poslovnog udjela u društvu postoje različite vrste prava na kojima se na različite načine zasniva založno pravo kao, primjerice, tražbine, dionice, udjeli u društvima osoba i investicijskim fondovima i sl. Kako zasnivanje založnog prava na stvarima ne utječe na pravo vlasništva, tako i kod zaloga udjela treba smatrati da založno pravo na udjelu ne utječe na pripadnost udjela njegovu imatelju - zalogodavcu. Založno se pravo na udjelu kao pravu ne stječe translativno kao što bi to bio slučaj kod cesije, već konstitutivno. Opće pretpostavke zasnivanja dobrovoljnog založnog prava na poslovnom udjelu jesu: osigurana tražbina, poslovni udio kao predmet založnog prava, pripadnost poslovnog udjela zalagodavcu, sposobnost zalagoprimca da stekne založno pravo na poslovnom udjelu, valjanost založnog ugovora (titulus) i odgovarajući način stjecanja založnog prava na poslovnom udjelu (modus). Više o tome vidi Miladin, P., Markovinović, H., „Založno pravo na pravu“, Pravo u gospodarstvu 46/07, str. 102. i dalje. i Gavela, N. i dr., Stvarno pravo, Zagreb, 1998., str. 722. i dalje.

119 Zakon o vlasništvu i drugim stvarnim pravima, Narodne novine br. 91796, 68/98, 137/99, 22/00, 73/00, 129/00, 114/01, 79/06, 141/06, 146/08, 38/09, 153/09, 143/12, 152/14. 
u zalog sklapa u obliku javnobilježničkog akta ili privatne isprave koju potvrdi javni bilježnik“. Istovremeno se osigurava učinak publiciteta navedenog pravnog posla tako što je javni bilježnik koji je sudjelovao u sklapanju toga ugovora dužan bez odgađanja umjesto članova uprave sastaviti popis članova društva u kojem će se navesti koji je poslovni udio založen i dostaviti jedan primjerak registarskom sudu, a jedan primjerak društvu. Usklađivanje pravila o dobrovoljnom sudskom i javnobilježničkom zalaganju poslovnog udjela s općom odredbom o zasnivanju založnih prava na pravu važan je doprinos pravnoj sigurnosti i poticajno je, kako za imatelje poslovnih udjela koji ih zalažu kao sredstvo osiguranja, tako i za njihove zajmodavce (založne vjerovnike). Ova izmjena trebala bi potaći zakonodavca da značajno izmijeni postojeći Zakon o Upisniku sudskih i javnobilježničkih osiguranja tražbina vjerovnika na pokretnim stvarima i pravima, ${ }^{120}$ odnosno da preispita pravnopolitičke razloge njegova donošenja. De lege ferenda treba ukinuti odredbu čl. 17. st. 1. Zakona o Upisniku sudskih i javnobilježničkih osiguranja tražbina vjerovnika na pokretnim stvarima i pravima kojom se propisuje konstitutivan učinak dobrovoljnog sudskog i javnobilježničkog založnog prava u Upisnik jer je ona konkurentna izmijenjenoj odredbi čl. 412. st. 6. ZTD-a. Radi pravne sigurnosti bitno je da postoji samo jedan modus zasnivanja dobrovoljnog založnog prava na poslovnom udjelu.

\subsection{Prestanak društva po skraćenom postupku}

Pravilo je da društvo koje ima dostatnu imovinu iz koje se mogu namiriti tražbine vjerovnika prestaje provođenjem likvidacije, a ako je društvo nesposobno za plaćanje i/ili prezaduženo, pokreće se stečaj. ${ }^{121} \mathrm{U}$ oba slučaja detaljno se propisuje zaštita vjerovnika. Društvo ne može prestati samo time što njegovi članovi donesu odluku o njegovu prestanku koja bi se upisala u sudski registar. Kako je riječ o pravnoj osobi koja ulazi u pravne odnose i koja ima imovinu, ti se odnosi moraju razriješiti, obveze podmiriti, a prava ostvariti, unovčiti stvari i prava i podijeliti članovima ono što ostane od imovine društva. To se postiže provođenjem likvidacije društva. ${ }^{122}$

Prestanak društva po skraćenom postupku, kao izuzetak od redovnog načina prestanka društva, značajna je novost uvedena odredbama čl. 472.a do 472.g Zakona.

120 Zakon o Upisniku sudskih i javnobilježničkih osiguranja tražbina vjerovnika na pokretnim stvarima i pravima, Narodne novine br. 121/05.

121 Likvidacija društva provodi se na temelju odredbi čl. 466. st. 1. t. 2., čl. 471. i čl. 472. ZTD-a. Društvo ne može prestati pukom odlukom članova. Kako je riječ o pravnoj osobi koja ulazi u pravne odnose i koja ima imovinu, ti se odnosu moraju razriješiti, obveze podmiriti a prava ostvariti, unovčiti stvari i prava i podijeliti članovima ono što ostane od imovine društva. Stečaj se provodi na temelju relevantnih odredbi Stečajnog zakona, Narodne novine br. 71/15. i 104/17, a tijela stečajnog postupka su sud, stečajni upravitelj, skupština vjerovnika i odbor vjerovnika (čl. 75. Stečajnog zakona). Stečajni razlozi navedeni su u odredbi čl. 5. st. 2. Stečajnog zakona.

122 Donošenjem odluke o njegovu prestanku nastaje razlog za prestanak društva i ono djeluje i dalje samo što mijenja cilj. Umjesto da vodi poduzeće radi stjecanja dobiti, obavlja radnje koje vode do njegova prestanka. Nema li dovoljno sredstava da podmiri obveze, pokreće se postupak stečaja. Nakon likvidacije ili stečaja, društvo se briše iz sudskog registra. Tako Barbić, J., „Novela Zakona o trgovačkim društvima u 2019.“, Zbornik 57. susreta pravnika, Opatija 2019., str. 55. 
Ne provodi se likvidacija nego članovi društva dijele njegovu imovinu prema planu raspodjele koji usvoje. Cilj je odredbi o prestanku društva da se vrijeme potrebno za prestanak društva skrati, a da se istovremeno ne umanji razina zaštite vjerovnika. Ako članovi društva tako odluče, društvo može prestati u skraćenom postupku bez likvidacije, osim onih društava kod kojih je propisan zakonski uvjet za obavljanje djelatnosti ili je nužna nečija suglasnost za djelatnost. ${ }^{123}$ Pored izričitog navoda da društvo prestaje po skraćenom postupku bez likvidacije, u odluci članova moraju se navesti podaci kojima se identificiraju društvo i njegovi članovi, kao i usvojeni plan raspodjele imovine društva. ${ }^{124}$ Članovi su pritom dužni dati izjavu da društvo nema nepodmirenih obveza prema radnicima i bivšim radnicima, niti nema obveza prema drugim vjerovnicima, a svaki se član društva obvezuje podmiriti, solidarno sa svim ostalim članovima društva, sve preostale obveze, pokaže li se naknadno da one postoje. ${ }^{125}$ Odluka članova i njihova izjava mora biti u obliku javnobilježničkog akta ili privatne isprave koju potvrdi javni bilježnik i mora se bez odgađanja prijaviti registarskom sudu, a prijavi treba priložiti i potvrdu da društvo nema nepodmireni dospjeli dug po osnovi javnih davanja kako su definirana poreznim propisima. ${ }^{126}$ Ako su ispunjene pretpostavke za upis, registarski će sud donijeti rješenje o prestanku društva po skraćenom postupku bez likvidacije. ${ }^{127}$ Članovi će se odlučiti za takav način prestanka društva koji su pravovremeno i valjano ispunjavali svoje obveze, pa je vjerojatno da vjerovnici, bilo subjekti javnog ili privatnog prava, neće ustajati s prigovorima protiv plana raspodjele imovine ili izjave o nepostojanju duga, odnosno žalbom protiv odluke registarskog suda. ${ }^{28}$ A contrario, ako je izvjesno ili vjerojatno da društvo ne ispunjava propisane uvjete za prestanak po skraćenom postupku, članovi koji postupaju sa zahtijevanom dužnom pozornošću neće se odlučiti na takav način prestanka društva jer društvu mogu nastati dodatni troškovi. Kao navedena alternativa provođenju likvidacije, ovakav način prestanka društva nije osmišljen za društva koja imaju nepodmirena dugovanja prema trećima ili nedovršene poslove. Ako se članovi društva koje je u takvom stanju odluče na prestanak po skraćenom postupku, njihov neuspjeh će samo opteretiti imovinu društva jer su društvu nastali nepredviđeni sudski ili drugi troškovi, a uspiju li od registarskog suda ishoditi pravomoćnost rješenja o brisanju društva, trebaju „strepiti“ još dvije godine koliko je propisani rok zastare za ostvarenje tražbine prema članovima društva koju su

123 Arg. ex čl. 472.a st. 1 i čl. 472.g ZTD-a. Odredbe o prestanku društva po skraćenom postupku unesene su u drugi dio, glava $\mathrm{V}$, odjeljak 6. Zakona koji sadrži jednu odredbu o ništetnosti društva kojom se upućuje na odredbe o ništetnosti dioničkog društva.

124 Čl. 472.a st. 2. ZTD-a.

125 Čl. 472.a st. 3. ZTD-a.

126 Čl. 472.b st. 1. i 2. ZTD-a. Registarski sud može zatražiti od članova dodatni dokaz kojim se potvrđuje istinitost navoda iz njihove izjave.

127 Čl. 472.b st. 4. ZTD-a. Postupak prigovora protiv toga rješenja propisuje se u čl. 472.c, a brisanje društva iz registra uređeno je odredbama čl. 472.d ZTD-a. Pravomoćnošću tog rješenja dijelovi imovine društva prelaze na članove društva sukladno planu raspodjele imovine. Odredbom čl. 70. st. 13. ZSR-a propisuju se uvjeti koji se trebaju ispuniti da bi registarski sud donio rješenje o brisanju subjekta upisa iz registra bez likvidacije.

128 Arg. ex čl. 472.b i 472.c. ZTD-a. 
vjerovnici imali prema društvu. ${ }^{129}$ Pokaže li se da postoje vjerovnici društva koji nisu namireni, njihova zaštita nakon prestanka društva svodi se na odgovornost članova društva za nepodmirene obveze. Vjerovnicima će posebno biti otežano namiriti tražbine protiv fizičkih osoba koje nemaju prebivalište ili boravište u Republici Hrvatskoj, ili koje su dostupne ali nemaju imovinu, ili protiv pravnih osoba koje su smišljeno pripremile „strategiju“ za zaobilaženje svojih obveza. Radi toga bi registarski sudovi u slučaju bilo koje sumnje ili dvojbe trebali koristiti svoja ovlaštenja da preispituju istinitost navoda iz izjava članova na temelju odredbe čl. 472.b st. 3. ZTD-a.

Otvorenim je ostalo pitanje kako sankcionirati članove društva koji pokrenu podjelu imovine društva prema planu raspodjele, unatoč tomu što znaju ili su morali znati da nisu ispunjeni uvjeti za takav način prestanka društva. Rješenje takvih situacija treba pronalaziti unutar nepisanog načela lojalnosti članova društva prema društvu i drugim članovima, pa troškovi uzrokovani takvom odlukom članova trebaju opteretiti imovinu tih članova, a ne imovinu društva. De lege ferenda treba izrijekom urediti način sankcioniranja članova društva koji pokreću skraćeni postupak, a da za to nisu ispunjeni uvjeti. Članove treba obvezati da društvu naknade iznos koje je ono isplatilo trećim osobama, primjerice s osnova izrade plana raspodjele imovine i sl.

Novost je u našem pravnom poretku da se poslovne knjige i dokumentacija svih trgovačkih društava nakon njihova prestanka povjeravaju na čuvanje Hrvatskoj gospodarskoj komori koja je dužna zaprimljene isprave čuvati i postupati s njima u skladu s pravilima kojima se uređuje postupanje s arhivskom građom i arhivima. ${ }^{130}$ Dobro je da se nije prenijela neka od ostalih ovlasti sudskog registra na tu ili neku drugu instituciju (koja nije sud) jer bi se, a contrario, narušila pravna sigurnost. Bilo pod krinkom blagodati brzine i ekonomičnosti, ili ne, uvođenje informatičke tehnologije ne smije biti izlika za umanjivanje ovlasti Trgovačkih sudova u registarskim stvarima.

\section{ZAKLJUČAK}

Prošlo je više od četvrt stoljeća od donošenja ZTD-a. Prilagodba složenom okružju slobodnog tržišnog gospodarstva, promjene koje se događaju unutar zemalja srednjoeuropskog pravnog kruga koje su pravo društava uredile po njemačkom uzoru, te obveza prilagodbe našeg prava pravu Europske unije razlog su svih dosadašnjih izmjena i dopuna. U devedeset članaka satkane su odredbe koje čine sadržaj najnovijeg Zakona o izmjenama i dopunama ZTD-a koji je, uz izuzetak odredbi koje su navedene u prijelaznim i završnim odredbama, stupio na snagu 20. travnja 2019. Do 10. lipnja 2019. trebalo se prenijeti obvezne zahtjeve iz Direktive 2017/828 u hrvatski pravni poredak. Koristeći tu priliku, odlučilo se opsežnije izmijeniti i dopuniti ZTD. Odluka je bila ispravna i kvalitetno se

\footnotetext{
129 Čl. 472.e st. 2. ZTD-a.

130 Čl. 472.f, a u svezi sa 382. st. 4. i 5. ZTD-a.
} 
odmjerio opseg izmjena i dopuna. Posebno se to treba naglasiti za izmjene i dopune zajedničkih odredbi ZTD-a. Za pozdraviti je novosti koje su se dogodile u svezi s općim odredbama, primjerice, o brisanju trgovca pojedinca, podružnice, upisa tvrtke, predmeta poslovanja, sjedišta, sudskog registra i sl. Dioničko je društvo usklađeno s obveznim zahtjevima iz Direktive.

Međutim, vrsnoća zadiranja u strukturu ZTD-a opada kada se razmatra sadržaj izmjena i dopuna odredbi o društvu s ograničenom odgovornošću. Odmjereni opseg izmjena načelno je dobar, ali se na pojedina rješenja treba kritički osvrnuti. To se u prvom redu tiče odredbi: o ulozima za preuzete poslovne udjele, o povećanju broja članova, i uopće svrhe postojanja, j.d.o.o.-a, o osnivanju društva na daljinu i prestanku društva po skraćenom postupku.

Osobna i solidarna odgovornost člana za obveze društva, premda ograničena na iznos visine temeljnog kapitala, nije u skladu s temeljnom povlasticom koju uživaju članovi društava kapitala - neodgovornost za obveze društva. Zaštita vlastitog kapitala društva i zaštita interesa vjerovnika uravnoteženo se ostvaruje institutima unosa i održanja kapitala društva i proboja pravne osobnosti, pa je suvišna i neodmjerena odredba o ograničenoj odgovornosti osnivača za obveze društva do visine iznosa neuplaćenih uloga. Nije dobro unutar ispravno podešenog mehanizma uravnoteženja interesa između članova društva i vjerovnika umetati „dodatke“ kojima se dodatno štite vjerovnici, još je opasnije da se pri tome ugleda na rješenja koja vrijede za društva osoba. Treću rečenicu čl. 390 st. 2. treba de lege ferenda ukinuti jer se njome narušava pravna sigurnost.

Članovi j.d.o.o.-a ne uživaju samo povlasticu osobne neodgovornosti za obveze društva. U njega ne trebaju unijeti ništa više od vrijednosti jedne kave, tako da ga mogu osnovati praktično bez uloga. Temeljni je kapital u njemu izgubio svoje izvorišne funkcije, a zbog opasnosti materijalne potkapitalizacije pogoršan je položaj vjerovnika koji nerijetko jedini snose rizik poduzetničkog pothvata, pa se opravdanim nameće pitanje opravdanosti postojanja toga društva u našem pravnom poretku. Naime, zbog suspenzije odredbi o unosu i održanju kapitala takvo će društvo već u početku biti opterećeno nastupom stečajnih razloga. Inicijalna potkapitaliziranost može se tada premostiti samo vanjskim kapitalom koji se namiče s osnova zajma člana društvu, ili zajma trećih osoba pri čemu će član društva svojom imovinom osiguravati povrat zajma. Ako se ne dogodi vanjsko financiranje, društvo će olako zapasti u krizu odnosno predstečajno stanje. Zbog usredotočenosti na ostvarenje pravnopolitičkog cilja lakoće i jeftinoće osnivanja društva, zakonodavac je zanemario pitanja osiguranja likvidnog startnog kapitala i zaštite vjerovnika. ${ }^{131}$ Time se potkopala sigurnost vjerovnika društva i istovremeno pooštrila odgovornost članova društva jer će se u slučaju materijalne potkapitalizacije moći primijeniti odredbe o proboju pravne osobnosti na temelju kojih će članovi izgubiti povlasticu osobne neodgovornosti za obveze društva. Kod nas nema objektivnog pritiska stranih trgovačkih društva, niti opasnosti da će naši građani ili trgovačka društva osnivati

131 Tako sa stajališta nama u tom dijelu poredbenog njemačkog prava vidi Goette, W., Fleicher, H., Münchener kommentar zum GmbH-Gesetz, 3. Auf., 2018., § 5a, Rn. 19. 
društva u drugim zemljama članicama i vratiti se poslovati u Republiku Hrvatsku, kao što je to bio slučaj s pritiskom britanskih Limiteda na njemačko gospodarstvo, a minimalni iznos temeljnog kapitala desetorostruko je niži nego u Njemačkoj, odnosno četiri puta niži od onog u Austriji. Nameće se pitanje o svrhovitosti postojanja j.d.o.o.-a. ${ }^{132}$ Imajući u vidu činjenicu da se pri osnivanju d.o.o-a može unijeti samo 5000 kuna, kao i to da se društvo može osnovati elektroničkim putem, ne vidimo potrebu da se urušava dobro uređeni sustav uravnotežene kapitalne zaštite između članova društva i njegovih vjerovnika prilikom poduzetničkog pothvata. Obesnaženje kategorije temeljnog kapitala nije valjano kompenzirano odredbama o rezervama kapitala i obvezi sazivanja skupštine društva. Navedene mjere djeluju pro futuro i ne otklanjaju početnu potkapitaliziranost društva, niti se njima dodatno štite vjerovnici društva. Premda zamišljen kao prijelazni oblik, svjedoci smo da je zbog, primjerice, dodatnih troškova povezanih s povećanjem temeljnog kapitala, „privremeno pravno odijelo“ j.d.o.o.-a postalo trajno. Značajan broj tih društava neuredno vodi poslovne knjige i ne izrađuje financijska izvješća, a to nije dobro niti za vjerovnike društva niti za njegove članove, jer je materijalna potkapitalizacija predmnijevani razlog za laku primjenu instituta proboja pravne osobnosti. Obesnaživanjem kategorije temeljnog kapitala proširuje se za razvoj gospodarstva poguban „lanac neplaćanja“ dospjelih obveza i dodatno opterećuje pravosudni sustav. Radi toga se de lege ferenda predlaže ukinuti odredbe čl. 390.a ZTD-a i propisati primjereni rok za prijelaz postojećih j.d.o.o.-a u d.o.o. Treba ostati dosljedan kapitalno orijentiranom sustavu zaštite vjerovnika jer je on stožerni potporanj prava društva s ograničenom odgovornošću.

Osnivanje društva na daljinu bez punomoćnika novost je u hrvatskom pravnom poretku. Premda je u šesnaest zemalja članica Europske unije omogućen takav način osnivanja društva, postoje značajni razlozi da se iz postupka osnivanja ne isključi javnog bilježnika kao jamca pravne sigurnosti i pružatelja stručne pomoći. Temeljni su razloga za to: a) radi nekritičnosti i osnivačkog optimizma u praksi će se olako osnivati trgovačka društva. To će izazivati poteškoće koje će se teško svladavati bez stručne pravne pomoći, pa će u pravilu osnivači takvih društava naknadno zatražiti stručnu pomoć prilikom bilo kakve izmjene i dopune društvenog ugovora, b) time se olakšava zaobilaženje odredbi o sprečavanju pranja novca, c) moguć je porast računalnog kriminaliteta koji se pojavio u nekim državama članicama i d) kod nas već postoji sustav elektroničkog osnivanja trgovačkih društava koji se može dopuniti. Niti njemačko niti austrijsko pravo ne otvaraju mogućnost osnivanja bez sudjelovanja javnog bilježnika. De lege ferenda javne bilježnike treba uključiti u postupak osnivanja trgovačkih društava radi autoritativnog utvrđenja identiteta osobe osnivača i pružanja prave poduke osnivačima društava. Uz pomoć današnjih sredstava komuniciranja nazočnost javnog bilježnika može biti i ,virtualna“/ on line tako da se i nadalje omogući osnivačima da društvo osnuju na daljinu bez papira, pečata i dodatnih potrepština. To bi se moglo učiniti ,iz fotelje“ iz bilo kojeg kutka

132 Minimalni iznos temeljnog kapitala je 25.000 eura u Njemačkoj ( $\$ 5$ st. 1. GmbH-Gesetz-a) i 10.000 eura u Austriji ( 6 st. 1. GmbH-Gesetz-a nakon izmjena i dopuna 2013.). 
svijeta. Na taj se način osnivače može podučiti o rizicima ulaska u poduzetnički pothvat i umanjiti mogućnost računalnih prijevara.

Radi zaštite vjerovnika, ali i imovine samog društva, de lege ferenda treba dopuniti odredbe o prestanku društva po skraćenom postupka, i osmisliti načine sankcioniranja članova društva koji pokreću navedeni postupak, a znaju, ili moraju znati, da za to nisu ispunjeni uvjeti.

Ne samo radi uklanjanja uočenih nedostataka, već i radi ispravnog uređenja hrvatskog bilančnog prava, ${ }^{133}$ zaključno se predlaže što je moguce prije prionuti izradi Nacrta buduće Novele ZTD-a.

\section{LIMITED LIABILITY COMPANY IN THE LIGHT OF AMENDMENTS TO THE COMPANY ACT OF 2019}

Provisions of limited liability companies are presented and commented on. These provisions were amended by the Novella to the Company Act of 2019. It was passed because of the introduction of solutions from the Directive (EU) 2017/828 of the European Parliament and Council 17 May 2017 to encourage long-term participation of shareholders. (further: Directive 2017/828) in the Croatian legal order. It also significantly interfered in the material regulation of limited liability companies. The provisions were changed on the roles for the taken business shares on control of business share, on simple companies with limited liability and the Act was widened with two completely new sections called: „Creating companies long distance without proxy “and „Dissolving companies using speedy proceedings “. The legal political aim to make the Croatian economy more competitive and more attractive to investors, was attempted to be achieved with easier both creation and dissolution of companies. The idea of simple companies with limited liability is discussed in detail and critically analysed is the widening of the number of founders of that company, and de lege ferenda suggests its dissolution. After presenting the new possibility of founding a company electronically, legal solutions are subject to criticism and the main reason of concern lies in the fact of excluding public notaries from the procedure of creating companies. In this way, not only does it make it impossible for founders to become acquainted with the rights, obligations, and risks they are subjecting themselves to by entering a business venture, it also buries legal security for a possible increase in cybercrime and for circumventing provisions on preventing money-laundering. The possibility of dissolving companies in speedy proceedings and measures to protect creditors is also commented on. In conclusion, a critical analysis is made of certain provisions and institutes of company rights with limited liability and de lege ferenda solutions are suggested which could, in the future, be woven into the new amendments to the Act Draft.

Key words: simple limited liability company, founding companies from a distance, dissolving companies using speedy procedures, creditor protection

133 O trgovačkobilančnim problemima u hrvatskom pravnom poretku vidi Miladin, P., Markovinović, H., „Ništetnost i pobojnost utvrđenih godišnjih financijskih izvješća“, Zbornik 57. Susreta pravnika, Opatija, 2019. str. 97. do 153. 